\title{
Sharing Multiple Perspectives on Burning: Towards a Participatory and Intercultural Fire Management Policy in Venezuela, Brazil, and Guyana
}

\author{
Bibiana Bilbao $^{1, *}$, Jayalaxshmi Mistry ${ }^{2} \mathbb{E}$, Adriana Millán ${ }^{1,3}$ and Andrea Berardi ${ }^{4}$ \\ 1 Departamento de Estudios Ambientales, Universidad Simón Bolívar (USB), Caracas 1080, Venezuela \\ 2 Department of Geography, Royal Holloway University of London (RHUL), London TW20 0EX, UK \\ 3 Centro de Investigación y Transferencia Rafaela, Universidad Nacional de Rafaela (CONICET), \\ Rafaela S2300, Argentina \\ 4 School of Engineering and Innovation, The Open University (OU), Milton Keynes MK6 7AA, UK \\ * Correspondence: bbilbao@usb.ve; Tel.: +44-7835740559
}

Received: 30 April 2019; Accepted: 28 June 2019; Published: 5 July 2019

\begin{abstract}
Although there is convincing scientific research for the role of Indigenous fire practices in sustainable land management, Indigenous peoples' involvement in policy-making is limited. This paper presents findings from a fire management workshop where experiences and perspectives were shared among 60 academic, government, and Indigenous representatives from 27 organizations from Venezuela, Brazil, and Guyana. The data, in the form of small group discussions, participatory drawings, whole group reflections, and videos, showed that although there was general acceptance about the central role of fire in traditional Indigenous livelihoods and its importance for protecting the biological and cultural diversity of ecosystems, there were also tensions around the past imposition of a dominant fire exclusion discourse of governmental institutions in Indigenous territories. Overcoming the gaps derived from different experiences and historical worldviews, and building mutual trust and respect were the main challenges when integrating multiple perspectives through the "intercultural interface" of institutions working on environmental management and governance. The elaboration of a common declaration and next steps in the framework of a "Participatory and Intercultural Fire Management Network", created during the workshop to enhance a sustainable fire policy, revealed the conviction of working together for Indigenous fire management legitimization and strengthening from all participants of the three countries.
\end{abstract}

Keywords: fire management; fire governance; Indigenous; traditional knowledge; intercultural; participatory; Venezuela; Brazil; Guyana

\section{Introduction}

Fire is a worldwide phenomenon, and despite the recent calls for global fire mapping, monitoring and modelling, [1-3], there is also an urgent need to focus on the human dimension of fire, and how different individuals, communities, and institutions view and deal with fire. Indigenous peoples, for example, have been using fire for millennia, and there is a growing and rich literature on how they use and manage fire, from subsistence activities such as rotation farming and hunting, as well as to control the spread of wildfires. These practices represent an indispensable and sustainable livelihood tool for Indigenous communities associated with their land management and cultural manifestation [4-9].

There is growing scientific evidence, recognized by academic and organizational/governmental communities, and which Indigenous communities have long understood, that Indigenous practices achieve multiple objectives, such as the protection of biological and cultural diversity and helping with climate change mitigation and ecological resilience [10-12]. However, Indigenous peoples' 
participation in policy-making determining the management of their own territories is very limited, and the use of fire by Indigenous and other local non-Indigenous communities has been perceived as a threat to biodiversity conservation and natural resource management by Protected Areas (PA) administrators, fire-fighters' bodies, and policy-makers [13-15]. Fire suppression and firefighting have been the dominant approaches to managing fire, although the exclusion of fire, especially in fire-prone ecosystems such as tropical savannas, promotes fires of greater intensity and extension due to the accumulation of combustible material [16-19]. This situation is expected to be exacerbated with climate change, and socio-cultural and demographic dynamics extend the periods and spaces of fire occurrence, as has been reported in recent mega and multiple fire events ${ }^{1}$ [18], which even the most sophisticated techniques and fire combat equipment cannot control [20-23].

Traditional Indigenous knowledge and practices have an important role to play in fire management and policy, where it can complement scientific knowledge to expand our understanding of its behavior and help find solutions to its negative impacts $[5,24]$. However, the exclusion of Indigenous communities from decision-making on fire management issues has caused distrust and historical conflicts preventing the generation of new approaches and joint agreements to the problem of fire [25-29]. Indeed, a key requisite for bridging knowledge systems and implementing joint knowledge production is the recognition and accommodation of different stakeholders' perspectives, as well as a space or platform for stakeholders to deliberate on the nature of the policy problem and the type of outcome [30-35].

In this paper, we present the findings from a fire management workshop involving academic, government, and Indigenous representatives from Venezuela, Brazil, and Guyana. The workshop took place during the first phase of a larger project, whose general objective was to develop a case for integrating Indigenous fire practices within government fire management policy ${ }^{2}$.

While there are common themes among the three countries in terms of negative perceptions of fire and Indigenous peoples, Venezuela, Brazil, and Guyana have different institutional approaches to fire management $[27,28,36]$. The workshop gathered Indigenous representatives from different ethnic groups: Pemón's Arekuna, Kamarakoto, and Taurepang from the Gran Sabana region of the Canaima National Park, Venezuela; Makushi and Wapishana from Roraima in northern Brazil; and Makushi and Wapishana from the Rupununi region in Guyana. Although these groups share Carib and Arawak ancestries and inhabit common territories in the central Guiana Shield region, they have different colonization histories under Spanish, Portuguese, and British rulers, with different languages and worldviews, along with different political and institutional developments about Indigenous issues $[37,38]$.

This workshop, therefore, offered a unique opportunity to generate common spaces of encounter to exchange perspectives, experiences, and historical and modern worldviews between Indigenous people, environmental administrators, and conservation governmental institutions, firefighters, and academics about the role of fire in these territories. Our aim in this paper was to analyze whether this platform for sharing multiple perspectives and knowledge could:

- Form the basis of a shared discourse on how Indigenous community-owned fire management could be supported and strengthened, and;

- Lead to concrete actions towards integrating Indigenous fire knowledge into fire management policies.

\section{Environmental and Historical Background of Fire Management in the Central Guiana Shield Region}

The core region of the Guiana Shield, in the tropical northern region of South America, encompasses the territories of Canaima National Park, Gran Sabana in Venezuela, Roraima in Brazil, and the Rupununi

\footnotetext{
https://news.mongabay.com/2019/06/brazils-roraima-state-at-mercy-of-2019-wildfires-as-federal-funds-dry-up/ http://www.cobracollective.org/portfolio/participatory-and-intercultural-fire-management/
} 
in Guyana (Figure 1). This area is characterized by very old and weathered soils (with high levels of acidity and aluminum toxicity, and very low nutrient content) laying on top of one of the most ancient geographical areas in the world (formed 3.6-2.7 billion years ago) [39]. The climate is isothermic (with little variations in temperature the whole year round, characteristic of tropical regions). The rainy season extends for 8-9 months with a peak between May and August to September and a slight dry season between December and March. Temperatures and precipitations vary spatially according to altitudinal gradients. In the high plateau of the Gran Sabana (800 and 1500 m.a.s.1.), mean annual temperature reaches $20.6{ }^{\circ} \mathrm{C}$, and the mean annual precipitation varies between 1600 and $2200 \mathrm{~mm}$. In the lowland savannas of Roraima which extend from the northernmost part of Brazil to the Rupununi River region in Guyana, average annual temperature and precipitation range between $26^{\circ} \mathrm{C}$ and $29^{\circ} \mathrm{C}$ and 1100 and $1700 \mathrm{~mm}$, respectively [5,40-46].

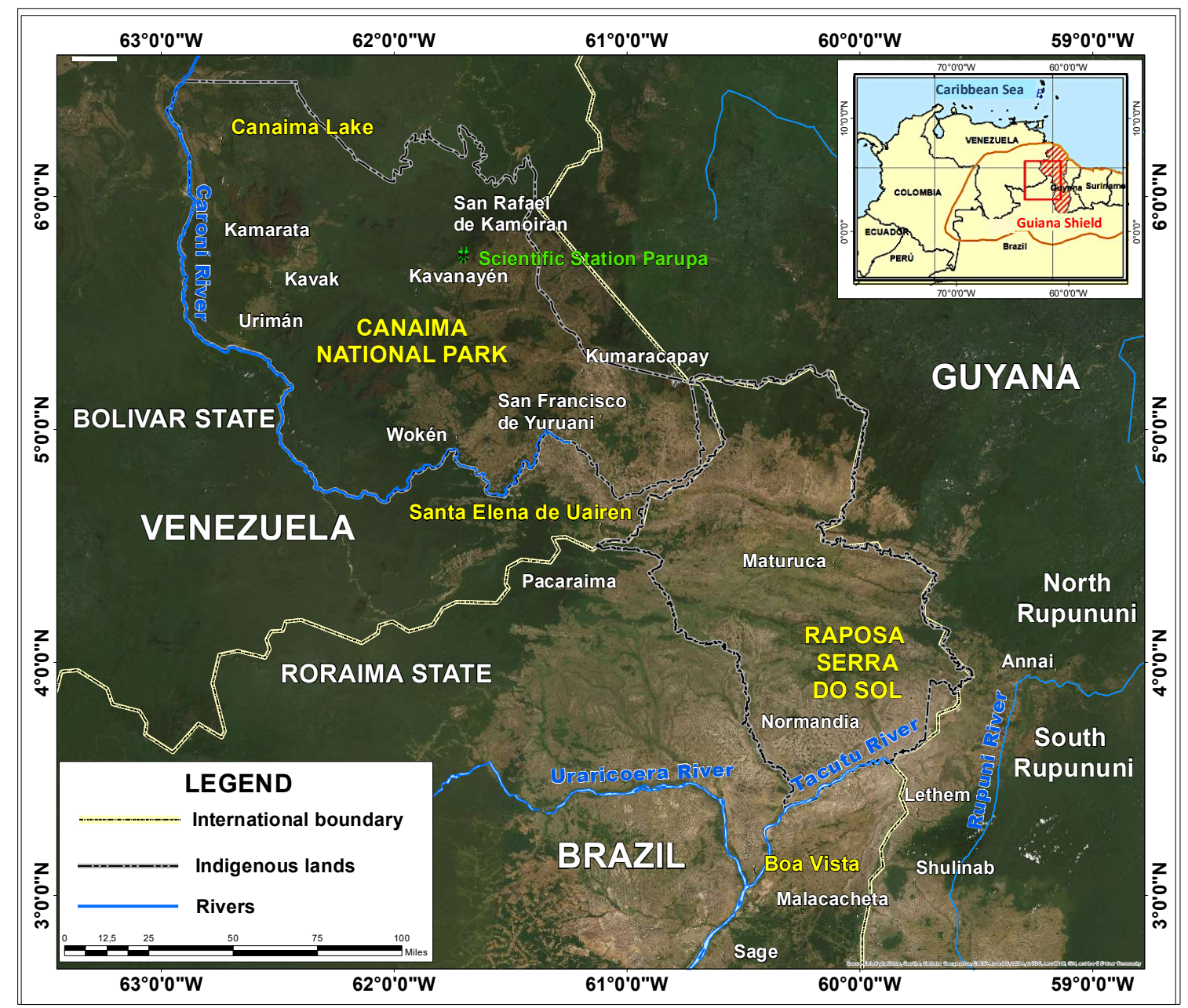

Figure 1. Map showing the locations inhabited by the different Indigenous communities from Venezuela, Brazil, and Guyana that attended the workshop. Green areas indicate woodland ecosystems and brown ones savannas. White circles indicate Indigenous communities, yellow circles indicate localities of reference (e.g. Boa Vista, capital of Roraima State of Brazil) and the bright green triangle indicates Scientific Station Parupa (the workshop place). Indigenous lands: Canaima National Park, Venezuela: Pemón Indigenous peoples (Arekuna, Kamarakoto, and Taurepang); Raposa Serra do Sol, Roraima, Brazil: Makushi and Wapishana Indigenous peoples; North and South Rupununi, Guyana: Makushi and Wapishana Indigenous peoples (map elaborated by Jonathan Rodríguez, Roberto Rivera and Bibiana Bilbao). 
These territories represent the home to the Pemón's Arekuna, Kamarakoto, and Taurepang Indigenous peoples from Venezuela, and the Makushi and Wapishana Indigenous peoples from Brazil and Guyana (Figure 1). In this environment, where more than $90 \%$ of fires are caused by humans, two different types of ecosystems coexist (Figure 1): fire-dependent vegetation of grasslands and savannas, dominated by fire-adapted species; and fire-sensitive vegetation of tropical humid and gallery forests types, dominated by tree species more vulnerable to the effect of fires [19,47-51]. Considering that ancient pre-Columbian human occupation of the Guiana Shield and surrounding Amazonas regions may date back as early as 11,400 to 10,000 years B.P. [52], the local sustainable resource management and biodiversity conservation practices performed by Indigenous peoples in forest and savannas areas $[10-12,36,50,51,53]$ during thousands of years appear to be effective for the maintenance of these coexisting ecosystems.

According to previous studies, Indigenous peoples from the Guiana Shield in Venezuela, Brazil, and Guyana have a sophisticated and controlled use of fire for agriculture, where biomass burning contributes to nutrient cycling, and soil quality and soil $\mathrm{pH}$ level improvement, allowing for crop sowing in forest areas. Fire has also been used by Indigenous peoples for hunting, fishing, to induce fruiting of edible wild plants, and to control high levels of savanna plant fuels, preventing the spread of wildfires into adjacent forests [4-9].

However, the ecological role of fire in the Guiana Shield region has been the subject of academic debate and controversy over recent years. Traditional theoretical ecological schools predict that under very wet tropical climate conditions the vegetation should be continuous forest cover, instead of the actual mosaic of coexisting forests and savannas, frequently found in this region. This has been used to support the prevailing view of fire as a threat to forest sustainability and biodiversity conservation, condemning traditional human uses of fire $[13,15,54,55]$. This academic perspective has been used in the region to support public policies that ban the use of fire in natural ecosystems, condemning in the public eye all Indigenous burning. Thus, Pemón Indigenous people face a backlash over the fires beyond the realm of scientific debate. Non-Indigenous Venezuelans (criollos) often call them (in a prejudiced way) as "quemones", a play on words in Spanish to refer to "Pemones" (plural of Pemón) as people who burn a lot. In the same way, in Brazil the Indigenous people have been pointed out as "savage" and "tenacious incendiaries" "selvagens" and "incendiários contumazes", in Portuguese) [55] who cause great fires. However, more recent research in Canaima National Park, Venezuela and in the savanna of Brazil reveal that Indigenous traditional fire serves as a tool to manage flammable materials and actually decreases wildfire risks $[4,5,8,9,53]$.

The pre-Columbian fire regimes maintained by semi-nomadic "land managers" in the savanna areas and in the rainforest borders over several millennia, experienced a dramatic change 500 years ago after European colonization, as a consequence of socio-economic and complex interlinked historical issues. Former Indigenous territories were transformed into agricultural and livestock production systems (based on monoculture crops and pastures, respectively), a process that brought about a marked decline in the natural systems [50,56,57]. From the time of European colonization, all agriculture and cattle ranch activities in the Amazon region and other South American lands have relied on deforestation and indiscriminate use of fire $[50,57,58]$ brought by the new settlers who did not adopt the sustainable Indigenous fire practices. The most important change introduced in fire regimes were extensive late dry season (LDS) fires instead of Indigenous small patchy burns in savanna ecosystems, and the recurrence of large, high-intensity fires in woodlands areas to eliminate native vegetation and transform it into pastures and plantations [50,57,59-61].

In the past century, the recurrence of large wildfires and the damage to the vulnerable ecosystems resulted in several administrative and legal actions undertaken by governments in the region, such as the creation of Protected Areas (PAs), e.g., national parks [62], and the suppression of wildfires-a 'zero fire' (or 'zero burning') policy-aimed at conserving the diverse and singular landscape [28,36,57,63]. The Environmental Penal Law in Venezuela [64], the Forest Code in Brazil [57,58,63], and the Forest Act 2009 in Guyana $[6,65]$ all contain elements that ban, exclude, and punish the use of fire in protected areas. 
The Pemón traditional Indigenous fire practices have been banned by National Institute of Parks (INPARQUES, acronym in Spanish) and National Electric Corporation CORPOELEC, acronym in Spanish), formerly Caroní Electrification C.A. (EDELCA, acronym in Spanish), the two major institutions in charge of conservation in Canaima National Park (CNP), Venezuela. The National Institute of Parks (INPARQUES) is the highest administrative authority in charge of Venezuela's national protected areas management, while CORPOELEC-EDELCA is the national electric company that runs a long withstanding initiative for fire prevention, detection, control, and combat in CNP, aimed to protect the Upper Caroní River basin, upstream of the Guri hydroelectric generation plant that supplies $70-80 \%$ of the country's energy demand [19,36].

In the past, local Pemón communities have been involved in bitter conflicts with these two institutions regarding the management of their traditional lands. In recent years, Venezuela has acknowledged and legitimized new rights for Indigenous inhabitants, including the collective intellectual property rights over their traditional knowledge, technologies, and innovations [66]. This new law has actually engendered a current unresolved and ambiguous conflictive situation with the environmental legislation, although it offers opportunities to renegotiate the policies and instruments applied in PAs inhabited by Indigenous people [28,67-69].

In Brazil, the responsibility for the execution of plans and actions related to the impact of forest fires lies with the National Centre for Prevention and Combat of Forest Fires (Prevfogo/IBAMA). Its initial programs answered to a 'Fogo Zero' philosophy ('zero fire') and were aimed at combatting and excluding fire and to "educate" the inhabitants of the Indigenous territories about its undesirable and negative effects. With time, PREVFOGO noticed that fire suppression and firefighting strategies began to generate problems of combustible material accumulation, creating conditions for large-scale wildfires. They also observed that the increase in drought due to the presence of climate change, together with the abandonment of traditional subsistence practices of many Indigenous communities, resulted in an increased occurrence of high-intensity fires, larger affected areas, as well as greater costs for firefighting activities. Considering these experiences, the Forest Code was revised in 2012, legalizing the use of fire management for conservation purposes in PAs of fire-prone environments $[57,58,63]$.

The Cerrado-Jalapão pilot project developed by the Brazilian Government since 2014 has applied an integrated fire management (IFM) approach, based on consultation with the local community to develop calendars and prescribed early dry-season burn planning in PAs to create patchy landscapes and reduce the probability of deleterious large LDS wildfires. This IFM program represents a paradigm shift from fire suppression to fire management policy in PAs and Indigenous territories, significantly reducing the occurrence of LDS wildfires and restoring the ecological and cultural importance of fire in savanna tropical landscapes $[27,28,58]$. However, burning vegetation outside reserves is not yet legally permitted [63] and the presence of Indigenous people in PAs is also forbidden or restricted [57]. This has generated conflicts concerning the Indigenous rights of occupation in these PAs as well as the application of late burns and other traditional practices of fire and natural resource management $[9,28,58]$.

In the case of Guyana, the institutional experience regarding fire policies is very recent. In 2010, the Guyana Forestry Commission (GFC) developed the National Forest Fire Management Strategy to inform local fire policy initiatives, such as the inclusion and use of the term "forest fire management" instead of "prevention" and "detection" previously included in the Forest Act 2009, and the inclusion of the role of forest fires in shifting cultivation and agriculture. In 2012, a new Ministry of Natural Resources and Environment was established (renamed Ministry of Natural Resources in 2016), under which all natural resource agencies are managed and through which decision-making about vegetation fires issues is centralized [36,65].

The foregoing account illustrates some of the historical burdens over the past 500 years that have affected fire regimes and their management decisions in the region. Despite recent advances regarding the legal framework and regulations related to fire management in PAs and Indigenous lands in Venezuela, Brazil, and Guyana, the management of Indigenous fires is not yet formally or legitimately 
recognized in these three countries. In this sense, the 'zero fire' policy not only has excluded fire management, but has also limited the Indigenous voice and opportunities for the coexistence of different visions or platforms to exchange different points of view. According to Howitt et al. [70], many intercultural settings are characterized by "complex legacies of social, economic and environmental injustice and involvement of multiple cultural groups", where " ... layers of historically constructed power relations and patterns of disadvantage and advantage are deeply entrenched in social, political and economic realities on the ground" ( $p$ 126). These hierarchical dominant patterns are also found in the territories covered in this study as they underpin historical conflicts about fire use and management between local Indigenous communities and national institutions responsible for natural resource management, revealing the existence of deep tensions and conflicting worldviews $[5,27,36,68,69]$.

\section{Materials and Methods}

A fire management workshop involving academic, government, and Indigenous representatives from Venezuela, Brazil, and Guyana was promoted and organized by the authors; it was held in the Scientific Station Parupa (ECP, acronym in Spanish) run by the CVG (Venezuelan Corporation of Guayana), located in Gran Sabana, Canaima National Park (Figure 1), in the southwestern region of Bolívar State, Venezuela, from 8 to 11 July 2015. The INPARQUES (Venezuelan Parks Authority) Fire Department, the Scientific Station Parupa (ECP), and the Indigenous community of Kavanayén in the Gran Sabana, provided logistic support.

Invitations were extended to Indigenous communities and governmental and research organizations who actively participated and took part in previous long-term participative action projects and fire collective experiments promoted by the authors in the central region of the Guiana Shield region of Venezuela, Brazil and Guyana [5,19,25-28,36] (see also footnote 4 in Results Section). Indigenous communities and organizations belonging to: Pemón's Arekuna, Kamarakoto, and Taurepang peoples from the Gran Sabana region in Canaima National Park, Venezuela; and Makushi and Wapishana peoples from Roraima in northern Brazil and from the Rupununi region in Guyana attended this workshop. Governmental institutions in charge of fire policies and programs in Venezuela and Brazil were also invited, as well as academics from ten different universities and research institutions with previous research experience in the region, most of them from Venezuela. In total, more than 60 Indigenous, institutional, and academic representatives belonging to 27 organizations attended this meeting (Figure 1, see Table A1 in Appendix A).

Workshop facilitators structured the engagement and deliberations amongst participants through a systems framework for participatory learning developed for working through complex environmental decision-making dilemmas [71,72]. The systems framework has a long history of application in different contexts where planning and managing decisions involve numerous and diverse visions and actors [73]. It uses a learning heuristic divided into four overlapping and iterative stages:

1. Explore context and connections;

2. Formulate systems of interest;

3. Identify feasible and desirable changes;

4. Take action.

In essence, the systems framework stages transition from an open, unstructured exploration of a complex situation, to gradually narrowing down the range of choices in order to carry out one or more practical interventions. The system framework is applied iteratively in that any action feeds back to expand participants' understanding of the context, to reformulate systems of interest, and to adapt the choice among feasible and desirable options. Thus, the framework acts as an ongoing process of collaborative learning amongst participants.

The systems framework was used in the workshop for the identification and analysis of the major issues related to fire management in Indigenous territories as recognized by different social actors, as well as the analysis of their views, opinions, and attitudes about these issues. This methodology 
suits the need to advance in fire public policy and management issues. Previous initiatives, in this sense, have proven to be of little effect and have also historically promoted social conflicts and exclusion of Indigenous people in the region, since they deny the rights of Indigenous communities to participate in the decision processes that affect their lives and their own territories. The inclusion of relevant social actors' visions is expected also to broaden the scope of possible alternatives to deal effectively with the socio-economic and environmental complexities involved with fire and burning, in the face of the challenges and risks posed by climate change scenarios in the region.

The aim of this first workshop was to facilitate the first iteration of the four system framework stages. Participants were first divided into three working group sessions focusing successively on: (1) analyzing the current situation with regards to fire management; (2) coming up with the ideal situation; and then, (3) developing an action plan to move from the current to the ideal situation. For the first activity, participants were divided into groups as follows: Indigenous Venezuela; Indigenous Brazil; Indigenous Guyana; Institutions Venezuela; Institutions Brazil; Academics Venezuela. For the second and third activities, the groups gathered participants according to their country of origin.

Each group had one or two facilitators who took notes and assisted with the discussions and activities. In addition, discussions and results presentations were audio and video recorded by Indigenous communities from the three countries (Figure 2).

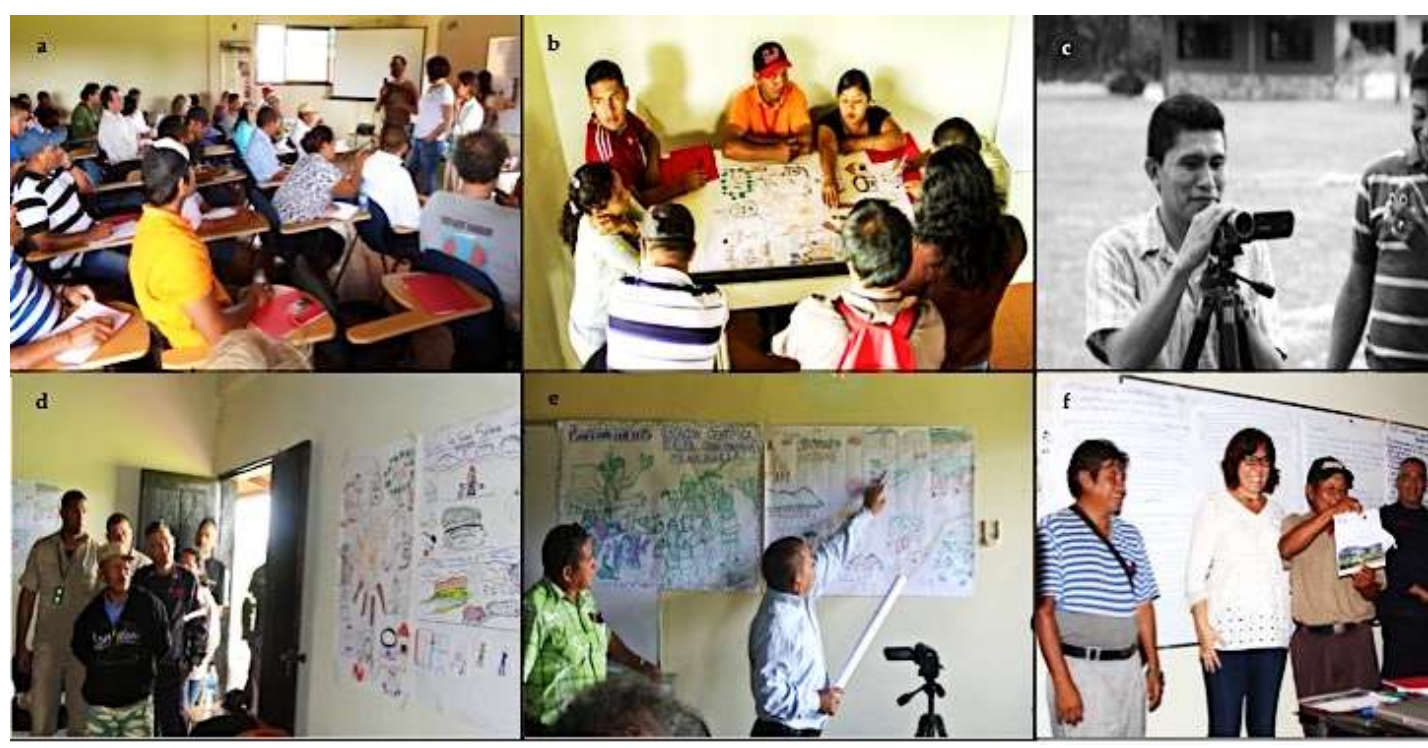

Figure 2. Illustrative images of the activities carried out during the workshop: (a) general view of the participants and organizers (in this image from left to the right: Andrea Berardi, Bibiana Bilbao, and Jay Mistry) of the workshop; this workshop gathered more than 60 Indigenous, institutional, and academic representatives from more than 27 organizations working on fire issues in the central region of the Guiana Shield of Venezuela, Brazil, and Guyana. (b) Group work formed by members of diverse Indigenous Pemón communities. (c) Participants from Indigenous communities from Brazil recording on video the activities of the workshop. (d) Firefighters from National Institute of Parks (INPARQUES, acronym in Spanish) and Vegetation Wildfires Control Program (PCIV, acronym in Spanish) of National Electric Company (CORPOELEC, acronym in Spanish) formerly Electrification of Caroní (Edelca, Acronym in Spanish), describing their rich picture results. (e) Indigenous representatives from Guyana presenting their results about traditional fire management. (f) Workshop organizers hand Attendance Certificates to all participants. In this image Valeriano Constati (center), leader of the Pemón people and Head of the Council of Elders of the community of Kavanayén, Gran Sabana, Venezuela, shows his certificate (from left to right: Filiberto Lambos, captain of the Indigenous community of Kavanayén; Bibiana Bilbao, Universidad Simón Bolívar; Valeriano Constati, Kavanayén Indigenous community; Mayor Miguel Matany, First Commander of the INPARQUES Forest-firefighters; Héctor Rodríguez, Head of Scientific Station Parupa, CVG). 
For the activity 1 session, participants were requested to focus on the creation of a collective group rich picture to represent their opinions about each task. Rich pictures formed the basis for discussions; these are drawings, pictures, symbols, and texts that express visual thinking and represent a particular situation or issue from the viewpoint(s) of the person or people who drew those [74]. Rich pictures are artistic and individualistic expressions, and therefore neither "right" nor "wrong". They were used to help gain an appreciation of the problem situation and provide a representation of how participants look at and think about the system [75]. At the end of the session, the groups shared their own rich pictures with the rest of participants allowing a general exchange of ideas and views among them in order to envision possible shared paths of solution to present-day conflicts.

During the event, English, Spanish, and Portuguese were used by the participants, from Guyana, Venezuela, and Brazil, respectively. Pemón, Makushi, and Wapishana Indigenous people could easily understand each other's native tongue, despite minor variants in some words and pronunciation. Special efforts were devoted to overcome linguistic barriers to reach understanding and agreement. The authors of this paper provided translations into each other's language to assure all participants understand and follow the discussions.

Along with the workshop discussions, the facilitators encouraged all participants to:

1. Express openly their own ideas, keeping respectful attitudes to other's opinions, as well as an open disposition to learn from this process;

2. Appreciate and value the contributions from all different stakeholders and Indigenous representatives;

3. Identify key issues of common interest to them;

4. Think about inclusive solutions where all stakeholders and Indigenous peoples could be included in all the stages of the process;

5. Identify and propose possible local actions to ensure an intercultural and participative fire management plan based on the rescue of Indigenous knowledge;

6. Negotiate a common path to deal with increasing risks and costs of wildfire occurrence in Indigenous territories.

Although a respectful and relaxed exchange of ideas prevailed along the discussions, tensions appeared at some points of the meeting due to the confronting opinions and views, which required strong facilitation of the group discussions, reminding participants about the importance of inclusion of all actors, Indigenous, academics, and technicians of governmental Institutions, and of identifying and negotiating possible paths to move forward.

Rich pictures, discussions, and audio and video materials collected from the different groups of participants were transcribed and comprise the data for this paper. Analysis of the data involved inductive coding of the raw data to identify viewpoints and arguments that emerged from the discussions, i.e., generating either divergence or convergence of opinions. The main results and agreements reached during the workshop were systematized and compiled in a report, which was sent to each of the participants. The contributions were included in a final version of the report ${ }^{3}$. This report also served as an input for this article.

\section{Results}

The Parupa workshop offered a unique occasion for different stakeholders from the three countries to openly share their views, consider some of the current risks and threats they face, appreciate different perspectives about fire management in their territories, and envision possible avenues towards new scenarios where Indigenous fire management can be recognized as a valid and relevant knowledge.

3 http://projectcobra.org/participatory-and-intercultural-fire-management-network/ 
This exceptional event allowed distant Indigenous communities to share and reaffirm their common Caribbean and Arawak origins and cultural legacies.

The attendance and participation of Indigenous and institutional representatives along the whole event was successful, thanks, in part, to the trust that the academic organizers (authors of this paper) had previously created with communities through the implementation of participatory long-term action research projects, and capacity-building activities intended to improve their own community solutions to challenges $[25,27,28,76,77]$. This laid the ground and established a safe space for initial discussions, as participants confidently shared their worries about the risks of wildfires and their impact on forest integrity and biodiversity conservation in their territories.

Having the workshop in the CNP, within Indigenous lands, was an important factor contributing to its success. According to Pemón usages, important matters should be addressed in general assemblies, in their own lands, consulting elders' opinions and including people from the communities, allowing enough time to listen to all participants in order to reach an agreement. This might be an important issue to overcome in future instances, since public servants generally work in centralized offices and headquarters located in the countries' capitals.

Another key point for a successful outcome of the event was the presence of high-level representatives from the institutions in the meeting, as it was mentioned by the Pemón Indigenous communities. Since several Indigenous leaders, including the president of the Council of Elders of Kavanayén, attended the whole meeting, they expected reciprocity, with partners of equal rank at the meeting. The participation of INPARQUES' Forest Fire Commander, who hosted the meeting together with the project researchers, was seen with much acquiescence by the communities.

The actual process of agreement that unfolded during the workshop (Figure 3) was the result of the dynamic that took place in the group and general discussions that led to: (a) the identification of key issues of common interest to all participants; (b) the mutual recognition of the stakeholders and Indigenous representatives involved and of the value of their contributions; (c) the need to learn from each other and to be included in all the stages during the search for solutions; and (d) the proposal of local actions to ensure an intercultural and participative fire management plan based on the rescue of Indigenous knowledge.

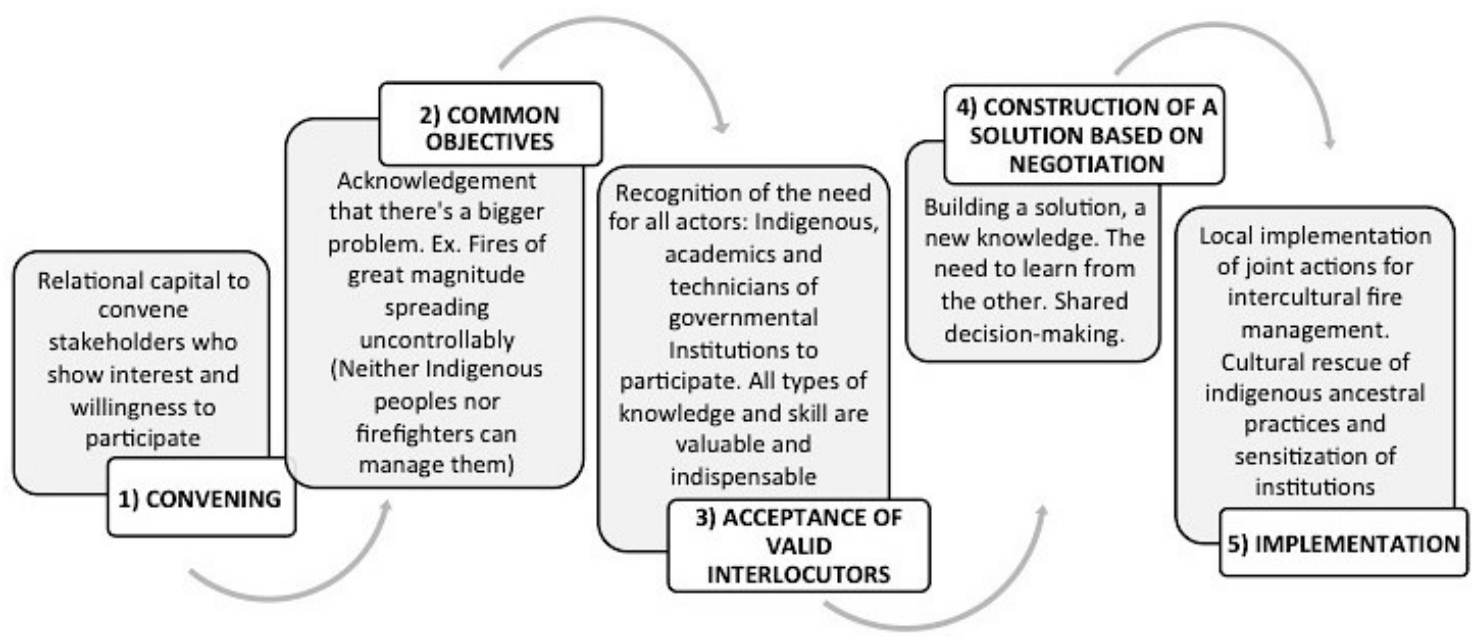

Figure 3. Intercultural fire management agreement process model.

The information obtained during the workshop allowed us to identify differences and similarities between each of the actors and perspectives, which were then organized according to the emergent topics or resulting categories that were identified (see Methodology for details). Major themes that emerged during the discussion were: (a) the importance of fire in everyday life and Indigenous culture (Section 4.1.); (b) institutional perspectives and approaches to fire management in Indigenous lands 
(Section 4.2.); (c) concerns about fire management in Indigenous lands (Section 4.3.); and (d) new approaches to an intercultural and participative fire governance (Section 4.4.).

\subsection{The Importance of Fire in Everyday Indigenous Life and Culture}

Actual contexts of Indigenous fire management in Venezuela, Brazil, and Guyana were explored and depicted by the participants in the form of rich pictures, shown in Figure $4 \mathrm{a}-\mathrm{c}$. All Indigenous participants highlighted the central role of fire for local livelihoods and the numerous uses and applications of fire in everyday activities, sharing openly and proudly this aspect of their culture, as "they certainly could not live without fire" (Captain of Kavanayén Pemón community, Gran Sabana, CNP, Venezuela), in spite of the huge challenges they face to protect and maintain it.

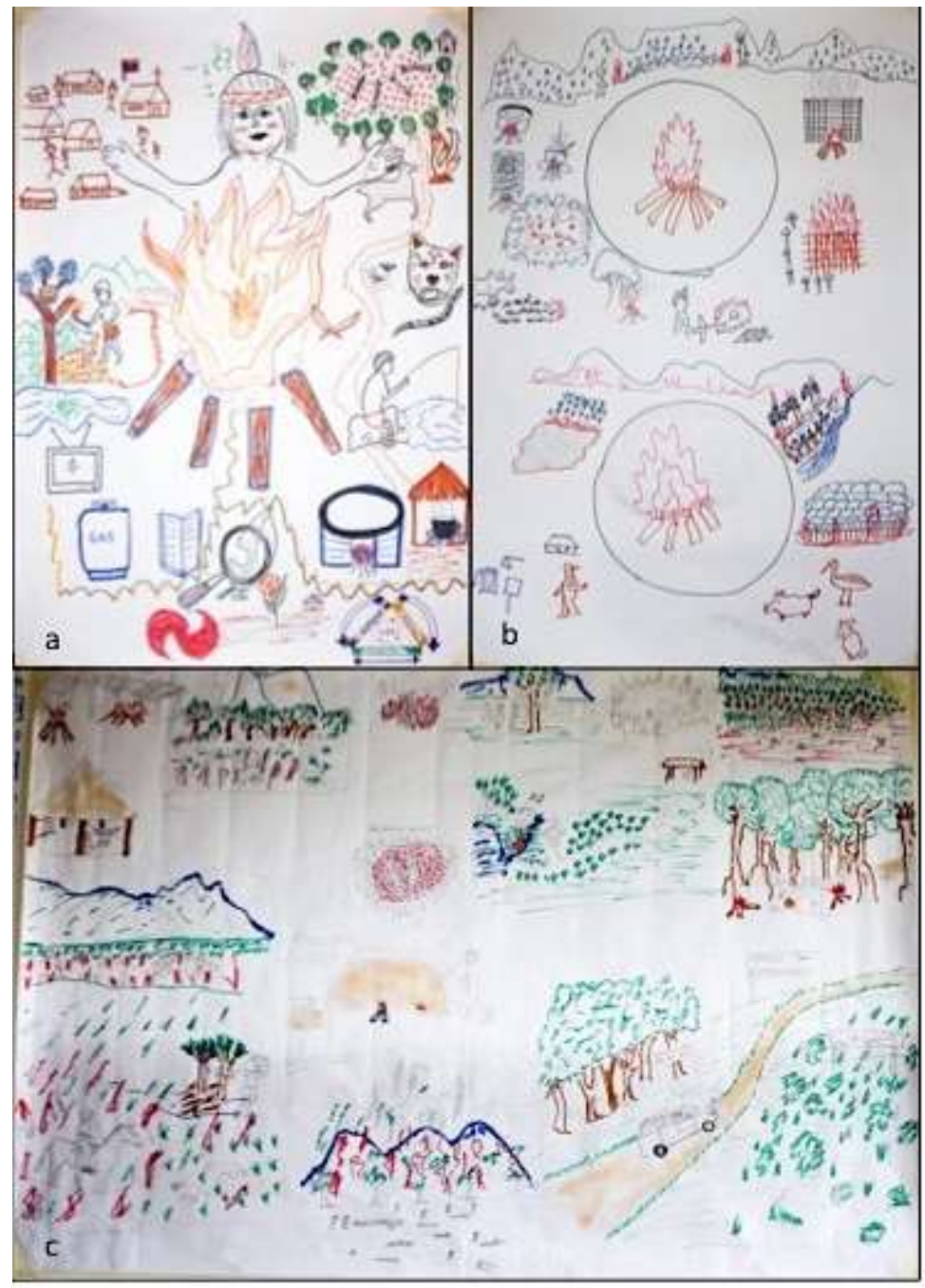

Figure 4. Rich pictures made by Indigenous groups: (a) Venezuela's Indigenous group included members of the Pemón Indigenous communities (Bolivar State, Canaima National Park). (b) The Indigenous group from Brazil was integrated with members of the Macushi and Wapishana communities from the Ethnoregion Sierras da Lua and Indigenous Land Raposa Serra do Sol, Roraima State. (c) Indigenous participants from Guyana included members of the Macushi and Wapishana communities from the North Rupununi District Development Board (NRDDB) and the South-Central Peoples Development Association (SCPDA), respectively.

Fire management represents a versatile and readily available technology that is applied by Pemón, Makushi, and Wapishana Indigenous people for a wide array of purposes, both in savanna and forest environments. Fire is used in family and collective practices (locally named Mayú by Pemón people) 
such as shifting cultivation, hunting, livestock management, fishing, and honey collection (smoking bees by smoldering various types of fuel), as well as in domestic daily tasks such as cooking (making cassava bread, tapioca, farinha, cachiri ${ }^{4}$, etc.) and food preservation.

Fire is also used in other common activities such as road clearing, protection from pests and predators (such as snakes and scorpions), construction (brick making), communication with smoke signals (i.e., early warning of events such as a successful hunt), ceremonies and ritual practices (i.e., use of fire to ward off evil spirits), and celebrations (with people sitting around bonfires). They also use fire for healing when they are sick.

Indigenous participants indicated that fire has an important role for soil preparation before crop planting in shifting cultivation practices carried out in small patches inside forests (conuco in Pemón language). These are exploited for 2-3 years and then left to rest in the form of barbecho (Spanish word to define secondary vegetation that develops after the conuco abandonment) over long periods, between 5 and 20 years, depending on the soil characteristics and surrounding forest vegetation. Yuca, succulent tubers (Manihot spp.), are the main crop for these Indigenous cultures.

"We make a conuco there, when we see that it is going to be [exhausted] we make a conuco farther away, $1 \mathrm{~km}$ or $3 \mathrm{~km}$ further, and we leave [the previous] to rest for a while and we move the conuco like a wheel. And when we get to this point [indicates with a gesture the starting point], about 5, 6, 7 or more years have passed, and this conuco is recovered to a new forest. This was the work of us Pemón people ... ". Head of the Elder's Council, Pemón Arekuna Indigenous community leader of Kavanayén for over 20 years, and former firefighter of CORPOELEC, Gran Sabana, Venezuela

Academics explained that the burning of plant material is required to release nutrients contained in the biomass and increases soil fertility, reducing soil acidity $(\mathrm{pH})$ and aluminum toxicity of very poor and weathered tropical soils. Makushi and Wapishana participants from Guyana noted that burnings are done against the wind (backfires) in early morning hours while flammable material is more humid, in this way, preventing fire spreading. Additionally, since the burning is fully completed in the morning, they still have plenty of light hours to be alert and control and restrain any fire spread.

Fire is widely used in hunting campaigns to ambush and trap prey. Deer is the most commonly hunted animal by the Pemón using fire, while the Makushi and Wapishana of Guyana use fire to catch tortoises, which are commonly found in dug holes in forested areas. Likewise, the Makushi of Brazil indicated they use fire to catch armadillos. The Pemón also burn the savanna to stimulate the production of tender grass shoots, transforming these places into feeding sites and hunting grounds for deer. The Pemón people also use fire to fish. Fire makes insects jump into water and attract fish.

The Makushi and Wapishana use fire to prompt pasture regrowth and provide food for cattle in the savannas of Guyana. This allows them to maintain cattle in areas managed by the community and prevent cattle from wandering away in search for food (and they also use fire to remove ticks from cows and mark them). Very few of the Pemón people practice cattle ranching. Foremost among the Pemón's reasons for burning the savanna is to create a mosaic landscape of vegetation divided by natural fire breaks that keep low fuel levels, preventing the spread of larger fires. They usually undertake this practice in the savanna-forest transitions-in order to protect forests from wildfires, assuring the continuity of their main livelihood activities (i.e., hunting, shifting cultivation, fruit and wood collection, among others).

Makushi and Wapishana use the patch mosaic system to both have fresh grass for cattle in different areas at different times and to protect savannas from the spread of wildfire.

"We also use fire to burn our savannas to get fresh grass, but we don't chose to do it like that, we do that what you call patches of savannas, burn this piece, burn that piece and burn that piece, right? ... so, you could see here we don't have specific firebreaks but our minds our traditional life said that we

4 An Indigenous fermented liquor made from the grated root of the manioc. 
have to prevent fire". Makushi Indigenous leader of the North Rupununi District Development Board (NRDDB), Guyana

Pemón, Macuxi, and Wapishana participants clearly emphasized that fire and its uses are linked to education and knowledge transmission and the maintenance of their culture.

\subsection{Institutional Perspectives and Approaches to Fire Management in Indigenous Territories}

\subsubsection{Firefighting Institutions}

National public policies in Venezuela, Brazil, and Guyana have historically regarded fire as a threat to ecosystem integrity and sustainability, especially those that spread without control. Official programs have promoted total suppression of wildfires or 'zero fire' policies to prevent damage to natural areas, and the adoption of sophisticated technical and expensive approaches to control and combat fires $[23,27,28,78-80]$. Traditional fire practices in Indigenous territories have, therefore, been restricted and criticized by local authorities and firefighting institutions, especially when they lead to uncontrolled wildfires.

Official plans have also included prevention and environmental education activities intended to teach the native population about the damage of fire and to introduce alternative agricultural techniques and practices.

The institutional rich picture presented by the Venezuelan group (Figure 5a) shows fire as central to the Gran Sabana landscape in Canaima National Park, the different uses by Pemón Indigenous communities, and the training received by the brigades, processes, and equipment necessary to fight fire. Representatives from both the INPARQUES and CORPOELEC-EDELCA Fire Control Program Brigades (PCIV acronym in Spanish) were included in this group. Both institutions also explained the differences between them, their perspectives, challenges, and concerns.

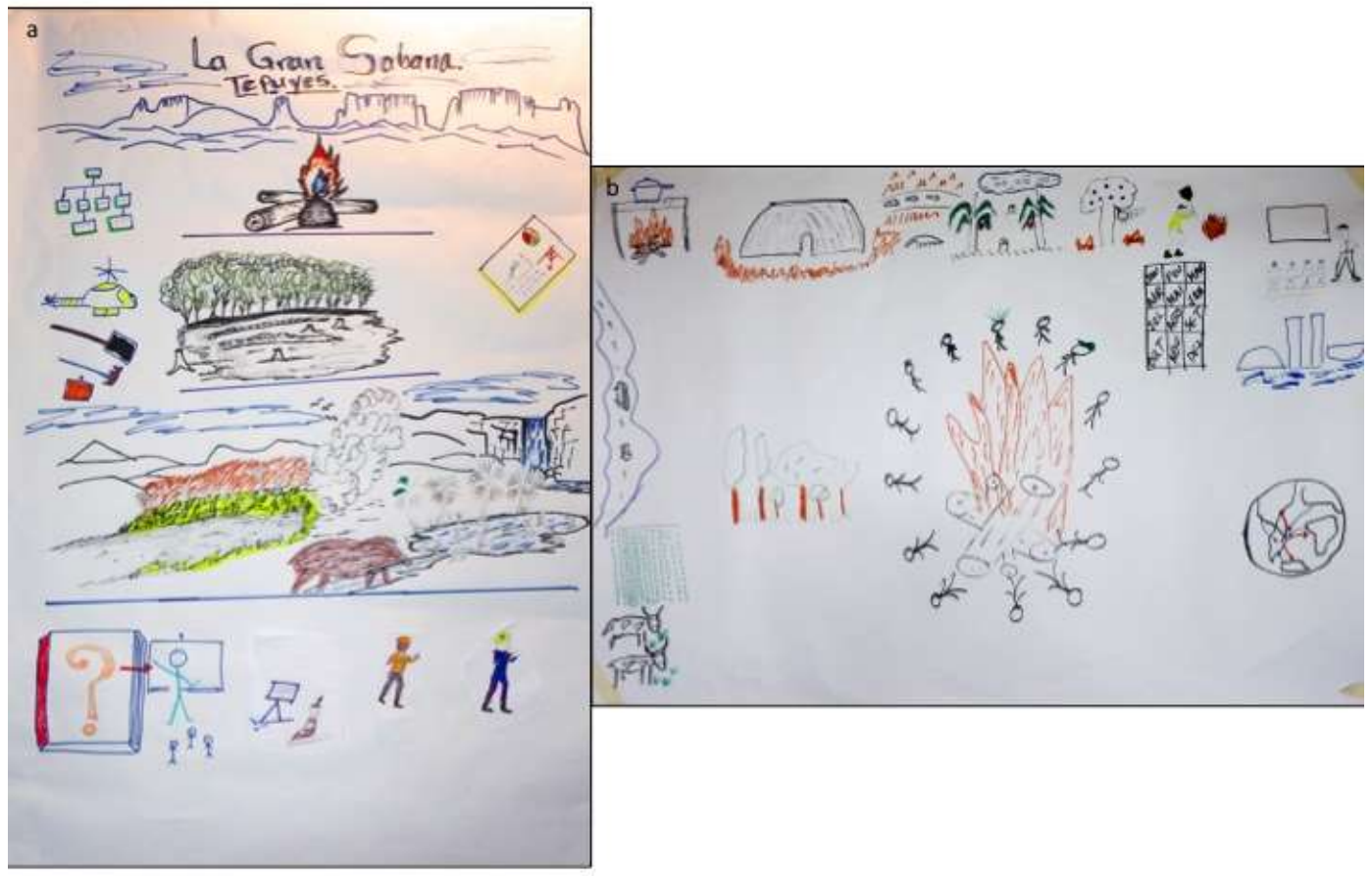

Figure 5. Rich picture made by the institutional groups: (a) Venezuela's group included INPARQUES firefighters and national park rangers, CORPOELEC-EDELCA PCIV firefighters and the coordinator, and the Parupa Scientific Station Director. (b) The Brazilian group comprised members of the Instituto Socioambiental Brasil (ISA), Centro Nacional de Prevenção e Combate aos Incêndios (Prevfogo-IBAMA), Instituto Nacional de Pesquisa da Amazônia (INPA-Roraima), and Fundação Nacional do Indio (FUNAI). 
During the presentation, PCIV Brigades emphasized that fire has always been a very important component in CNP. Problems arise when local burnings get out of control and become big wildfires posing risks to forest cover in the Gran Sabana and affecting Pemón Indigenous food production and resource availability. The loss of forest cover also affects hydrological cycles in the region and increases the amount of sediment by erosion that is deposited in water bodies and dams. They also highlighted the great practical experience acquired by PCIV. After more than 30 years of continuous operation, they have an extensive knowledge of the region, training of its staff in technical aspects of prevention, detection, and fire fighting in the upper basin of the Caroní River included in the Gran Sabana region of the CNP. The PCIV Brigades only work during the first attack against wildfires and are mostly composed of Indigenous Pemón members. They are aware of the importance of fire for the communities, the traditional methods of management, and the challenges that Pemón Indigenous communities face, taking into account the loss of traditional fire knowledge. They usually offer support during Indigenous shifting cultivation burns, to keep fire under control and avoid big wildfires. However, Indigenous Pemón PCIV members do not have the same status as official firefighters and can only reach the status of Chief of Brigades or Coordinator, with higher positions going to non-Indigenous people based outside the Park. Fire policy is, therefore, defined at higher hierarchical levels outside the Gran Sabana, at the company headquarters. In recent years, the program has suffered severe budget cuts, affecting their performance and achievements.

On the other hand, the INPARQUES forest firefighters' presentation focused on clarifying how they differ from the brigades of the PCIV. Although both have similar objectives (prevention, control of fires, and appropriate use of fire by Indigenous communities), differences derive from personnel experience requirements and organizational structure. The INPARQUES firefighters' body is composed of personnel with professional training, which obey a hierarchical structure headed by the president of the institution. This clarification intended to explain why some overlapping of obligations and responsibilities among the two organizations occurred when fighting a vegetation fire within the CNP. These differences in professional training as well as the overlap in firefighting functions in the park have generated tensions between these two groups, which became evident during the presentation. Unlike the PCIV brigades, INPARQUES firefighters are not permanently located in the CNP and they only attend very dangerous and out of control wildfire events. At present, the Fire Department of INPARQUES is planning to establish three permanent operation centers in Gran Sabana. The INPARQUES firefighters pointed out that joint work with EDELCA-CORPOELEC is planned in order to take full advantage of the technical and operational capacities of both institutions.

As an organizer of the workshop, the INPARQUES firefighters displayed a leadership role during the event that impressed the directives of the PCIV, who acknowledged that they had lost spaces of dialogue with local communities and leadership in relation to fire management in the region. Thus, although INPARQUES firefighters have historically been very restrictive about fire use in the CNP, during the Parupa workshop they adopted a more open attitude to work more closely with local communities and institutions:

\section{"We must enhance working together with communities, keeping a fluid communication. [We must also ... I prepare communities in fire handling and control techniques and participate with them in their burning activities. It is important as well not to obstruct their activities; for instance, when they are burning for hunting purposes, we shouldn't combat that fire, since prey might escape and that would create a conflict. This happens when there is no proper communication". Pemón Indigenous Park Ranger of the CNP, INPARQUES, Venezuela}

The rich picture created by Brazilian institutional members from Prevfogo/IBAMA (Figure 5b) represented the need to work together with Indigenous communities, acknowledging the various uses of fire in Indigenous life, as well as their concerns about the current political situation in Brazil and the strong lobby of rural stakeholders against Indigenous peoples. According to Brazilian firefighters' institutional experiences, "zero fire" policies are ineffective and no longer viable to prevent wildfires, since fire suppression and firefighting strategies favor combustible material accumulation, 
creating conditions for large-scale wildfires. These policies, together with an increase in droughts due to the presence of climate change, profound socio-cultural changes, and the abandonment of traditional subsistence practices by many Indigenous communities, have resulted in increases in the occurrence of high-intensity fires and the extension of affected areas, as well as in the investment costs of firefighting activities.

"...We had the determination of 'zero fire', that fire must always be fought; however, we came to the conclusion that 'zero fire' is impossible, we have to learn to live together, learn to manage it, so that the positive side of fire can be used ... ". Firefighter from IBAMA/PREVFOGO, Brazil

They considered that instead of 'zero fire', an integrated fire management (IFM) approach that incorporates Indigenous communities and their traditional fire management knowledge (e.g., fire calendars), together with technical and professional practices, has improved fire management. This integrated approach requires extensive technical training efforts to cover the vast territory of Brazil, as well as increasing public and political national awareness about the importance and value of protecting Indigenous traditional knowledge. This process may face opposition from some national sectors, such as the "fazendeiros" (landowners) that refuse to acknowledge Indigenous people's land rights. They also emphasized that it is necessary to exchange knowledge with other countries that are developing fire management experiences with Indigenous communities.

The Guyanese Indigenous representatives explained that the country does not have a public fire management system or firefighting institution (apart from urban fire stations), since Guyana is a very young country established only 50 years ago after becoming an independent nation from the United Kingdom. Nevertheless, natural resource management government officials and environmental organizations have promoted anti-fire discourses in the public domain.

\subsubsection{Academics}

The academics group comprised participants from Venezuelan universities and research institutions. Their rich picture (Figure 6) acknowledged the importance of fire to the Indigenous peoples, but also reflected the fact that there is still a strong academic lobby against them, blaming them for causing environmental degradation. They highlighted that even today many academics do not consider Indigenous knowledge valid because of

"the absence of solid scientific foundation". Researcher from Instituto Venezolano de Investigaciones Científicas (IVIC)

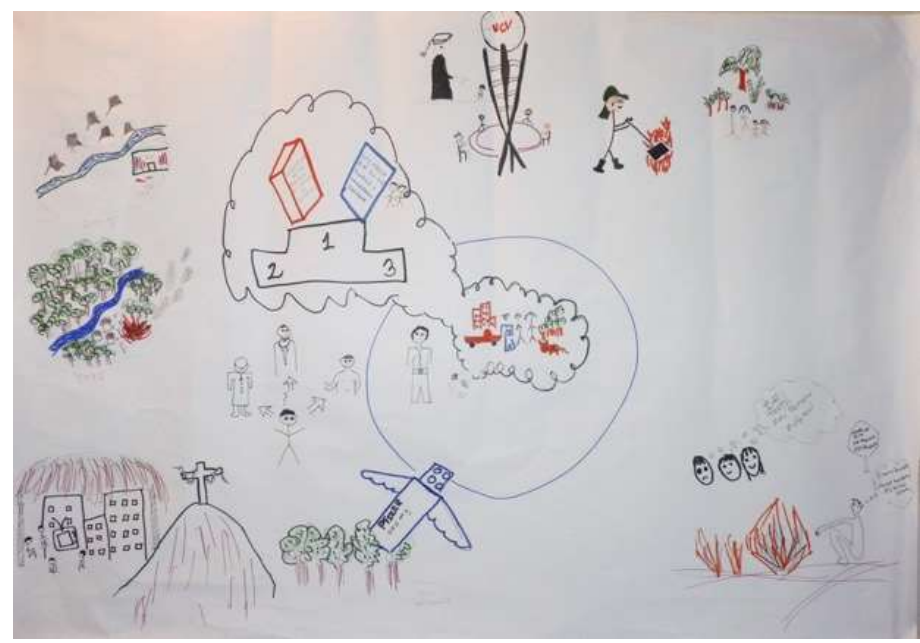

Figure 6. Rich picture drawn by members of the academic group. This group comprised researchers and students from: Universidad Simón Bolívar (USB), Universidad Central de Venezuela (UCV), Universidad Bolivariana de Venezuela (UBV, Santa Elena site), Instituto Venezolano de Investigaciones Científicas (IVIC), and Universidad Nacional Experimental Indígena del Tauca (UNEIT). 
In their presentation, they pointed out that, in spite of some recent and serious efforts undertaken by USB and IVIC researchers, natural and historical studies about the meaning and application of traditional fire Indigenous practices are scarce, and in many cases, inadequate. In the past, this lack of understanding has encouraged dismissive attitudes toward Indigenous fire management knowledge by governmental institutions. In their opinion, public policies and institutions promote the adoption of Western ways of living, increasing Indigenous communities' dependency and vulnerability, and contributing to the loss of Indigenous knowledge and culture, which are key elements for their autonomy, food sovereignty, and survival. They considered that in order to change this situation, major changes should be introduced in the laws and rules applied to Indigenous communities, as well as in fire management plans, allowing "Indigenous-controlled" prescribed burning practices in natural areas to reduce the amount of flammable material.

The academic group also pointed out that, although the lack of visibility of Indigenous culture in academic spaces still remains, there are some initiatives and long-term participative action projects ${ }^{5}$ that need to be acknowledged and extended.

"[These projects] ... have provided the ecological basis of traditional Indigenous fire management and materialize the inclusion and integration of Indigenous knowledge and practices in the decision-making process and an intercultural governance. They must continue to be supported". Professor at Universidad Central of Venezuela and Rector of Universidad Indígena del Tauca, Venezuela

\subsection{Concerns about Fire Management in Indigenous Lands}

Different stakeholders and Indigenous representatives expressed their own concerns about the difficulties and conflicts experienced in dealing with fire management issues in Indigenous lands.

All Indigenous participants also observed the increasing occurrence and severity of fires of higher intensities that affect their activities and ecosystems.

"Fire is man's friend, but wildfire is his enemy". Captain of the Kavanayén Pemón Indigenous community

\subsubsection{Lack of Indigenous Knowledge and Practices Transmission}

Indigenous participants expressed major worries about the loss of traditional Indigenous practices. Pemón people from Venezuela manifested concerns about the general loss of interest of the young people to learn from their grandparents. Although fire is still used for ancestral purposes by Pemón Indigenous people, recent cultural changes have brought new technologies and ways of living, creating "other needs" that appeal to young members of the communities. The proper traditional ways of applying and using burning is being forgotten, increasing the risks of uncontrolled wildfire occurrence.

Several Indigenous representatives from Venezuela, Guyana, and Brazil concurred that local bilingual schools are not intercultural, and they considered those as places for learning foreign knowledge, limiting the transmission of their own ancestral wisdom. In the past, children and young people used to share plenty of time with their grandparents listening to stories and taking part in daily activities (farming, hunting, fishing, etc.), assuring the practical transmission of their knowledge; while nowadays, children spend more time at school, losing opportunities to learn their traditional ways and practices. Likewise, young Indigenous people are being attracted by more lucrative occupations such as mining, abandoning traditional activities and the natural spaces of transmission and application of ancestral knowledge.

5 Participative action research projects funded by the National Science-Financing Institution (FONACIT), and supported by national and regional governmental development institutions (CVG, CORPOELEC-EDELCA, and INPARQUES): IAB (Interactions Atmosphere, Biosphere of the "Gran Sabana"), RISK (Risk Factors in the Reduction of Habitats in Canaima National Park: Vulnerability and Tools for Sustainable Development), and APOK (Fire in Pemón Indigenous language, Ecological and Traditional Knowledge Bases of Fire of Pemón People: Local Solutions for Global Climate Change Problems). 
"When we followed the tradition of our ancestors, the Indigenous lived peacefully without bothering anyone, but now we are seeing many consequences of having formed a [permanent] community, of having integrated our children to the studies of the school... We are seeing that our children lost all our culture, now everything is with the computer; instead of studying, they are looking for cartoons there and in the TV; that's not study... ". Head of the Elder's Council, Pemón Arekuna Indigenous community leader of Kavanayén for over 20 years, and former firefighter of CORPOELEC, Gran Sabana, Venezuela

Makushi and Wapishana participants from Guyana pointed out that Indigenous fire practices without appropriate knowledge cause significant damage to the forests, savannas, and morichales ${ }^{6}$, which are key areas for obtaining food and daily basic resources. Furthermore, the change from collective to more individual work was also pointed out as an important factor for large wildfires:

"... Each one takes care of his own farm for example, and if the fire is out of control, there is not a large team to help him, thus increasing the chances of the burn entering adjacent forest". Makushi Indigenous leader of the North Rupununi District Development Board (NRDDB), Guyana

Makushi people from Terra Raposa Serra do Sol in Roraima, Brazil also expressed concerns, as now, fire is generally out of control in their territory. They explained that, in the past, people used to be organized and work together to plan crop production and burns:

“... We had an Indigenous calendar for burnings. Now each person does his own thing and makes fire alone without a plan or knowledge ... ". Makushi Indigenous leader, Conselho Indigena de Roraima (CIR), Comunidade da Maturuca, Terra Raposa Serra do Sol, Roraima, Brazil

\subsubsection{Climate Change Effects on Wildfire Behavior and Regimes}

Makushi and Wapishana people from Guyana explained that some uncontrolled fires are related to climate change. With climate change, it is becoming more difficult to predict the rains, so as soon as there is a hint of the dry season, people go by motorcycle to the field and take advantage of the dry weather to burn. These fires can become uncontrollable and cause a lot of damage, especially in the seasonally flooded humid areas where the fish haul is decreasing. These fires also generate air pollution and contribute to global warming.

Similarly, Pemón people have detected the severity of the dry season and the increase in air temperatures; they also consider that the unpredictability of the weather has severe consequences on the spread and duration of large wildfires and their Indigenous practices.

"Climate change has affected fire behavior. When the grandparents lit fire in the conuco they knew that after the drought came rain. But not now; the seasons have changed. Thinking that it is going to be like the old days, the Indigenous people of nowadays light a fire and a certain time goes by without raining. It is sad to see large burned areas without being able to sow". Pemón Indigenous teacher of Escuela Técnica Agropecuaria de Kavanayén (ETAK), Gran Sabana, Venezuela

Participants from the Brazilian Makushi community also expressed serious concerns about how uncontrolled fires entering forests cause degradation, affecting areas of natural water sources. They consider that these erosive land processes will eventually affect the quality of life of Indigenous communities.

Representatives from firefighting institutions were worried about the threats that uncontrolled wildfires pose to biodiversity and river basin conservation; in their opinion, Indigenous traditional burns should be applied by experienced members of the communities to avoid fires getting out of control. According to firefighters' experiences, climate change has created conditions of higher temperatures and intense droughts that promote wildfires of greater severity.

6 Mauritia flexuosa palm swamps. 
"... We must still continue fighting this type of fire to protect the most vulnerable forest and those fires Indigenous people cannot control". Mayor Miguel Matany, First Commander of the INPARQUES Forest firefighters, Venezuela

For their part, the Brazilian PREVFOGO brigades also agreed that the drought severity had increased and that they have had a very strong impact on the propagation and occurrence of wildfires over Indigenous territories. Wildfires pass repeatedly over the same areas in subsequent years, delaying their recovery. They explained that there are not enough workers in their department in order to attend the needs of fire prevention and fire fighting in all Indigenous territories. Preventive work is needed throughout the whole year and the fire brigades' work should extend beyond the current six-month contract.

\subsubsection{Tourism}

Tourism was also blamed as a source of wildfires. The participants of the Guyanese Makushi community indicated that travelers crossing the territory start fires, which usually spread out of control.

\subsubsection{Exclusion of fire Indigenous Practices: 'Zero Fire' Policy Implementation}

On the other hand, Brazilian institutions expressed serious concerns about the political proposals made by the rural agribusiness lobby in the National Congress of Brazil, which seeks to withdraw rights acquired by Indigenous peoples such as the demarcation and implementation of their territories. These "fazendeiros" are a very strong and powerful economic group in Brazil, and they intend to weaken environmental legislation to facilitate soybean cultivation and mining. These "fazendeiros" claim that Indigenous territories are very large and unproductive, since Indigenous people do not want to work (in the Western sense).

The major concern shared by all groups of participants referred to the application of diverging perspectives of fire management in Indigenous territories. Indigenous communities perceive that institutions have historically promoted narrow and rigid perspectives and imposed their own vision of fire control and exclusion, refusing to acknowledge Indigenous fire management. On the other hand, institutions have considered the use of fire by Indigenous communities as an obstacle to natural areas conservation policy and to proper implementation of fire extinction and control strategies.

During the discussions related to how to implement an action fire management plan to move from the current to the ideal situation, direct mutual allegations between Indigenous and institutional representatives, gave rise to high tensions that were potentially damaging to the positive atmosphere of dialogue and exchange that prevailed during this event. Indigenous participants expected to have a leading role and an active involvement in the decisions concerning their territories, in contrast to being passive recipients of the choices imposed by the institutions. Indigenous participants insisted on being involved as equal partners in all stages and decisions related to fire management in Canaima National Park. They resented INPARQUES for considering biodiversity conservation more important than preserving Pemón traditional cultural legacy, when they believe that both are equally important.

"The Gran Sabana has been [here since] ancestral times, since it was created by the Almighty, and it has been a National Park since 1971 or 1972... and it was decreed without the knowledge of the Indigenous people, without telling the Indigenous people ... When the National Park was decreed... a director from INPARQUES came to Kavanayén and told me, since I was the captain: 'Look, sir, this is a National Park; you can no longer cut a stick, you can't make a conuco, you can't burn at the head of the rivers...because this is a Park, otherwise you will be penalized.' I told him ... 'It seems to me that now we're not bothering the government, we're not asking the government for daily bread. Here we are living in our environment, without bothering anyone, we have our conuco, and we know when we are going to do it"...We don't want that arrogance, we don't want them to come and tell us: 'Look, whatever the institution says, whatever the legal part says, this is it, you're going to do this' No! ... [We ask:] who is the one who pollutes the most in ... the planet? [It's] the big industries, which 
are permanently, all year round, smoking and smoking. And where [in this case] are the scientists, where are the environmentalists, where are the institutions, where are they? [Instead,] we are all here fighting right now for a smoke, because [some Indigenous people] burned a savanna...". Head of the Elder's Council, Pemón Arekuna Indigenous community leader of Kavanayén for over 20 years, and former firefighter of CORPOELEC, Gran Sabana, Venezuela

This situation was overcome through strong facilitation of the group discussions. The participants were invited to ponder the benefits and achievements over the last years. It was proposed that they value the efforts made, the capacity for dialogue acquired and the experiences of joint learning between the different stakeholders and Indigenous communities' representatives. Based on these considerations, the facilitators requested that the participants evaluate the two possible alternatives to follow: (1) build a common path of action through the understanding and negotiation of different positions, perspectives and interests or (2) going on each one their own separate and confrontational ways, bringing back the historically conflictive situations of the past. Additionally, the facilitators explained that learning pathways would not be free of mistakes, and that misunderstandings among the parties would appear, demanding mutual trust and special efforts to develop a new common language that enabled understanding. After this impasse, the president of the council of elders accepted the proposal to go all together, as long as all parties committed to respect the dynamics of consultation in the assemblies of the Pemón people about plans and actions. On the other hand, the INPARQUES authorities ratified the willingness of the institutions to assume new guidelines in terms of integration with the Pemón communities and to jointly define the destinies and activities of those territories.

"This is not the INPARQUES of the 1970s; this is a very different INPARQUES, which is besides you [referring to Indigenous communities] ... We start from the principle that it shouldn't have been like that and we don't want it to continue to be that way [referring to past un-consulted decision-making from public institutions]. [Now,] you have an INPARQUES with whom to propose things [in a different way] from the one used in the 1970s... As firefighters, we responsibly assume that the problem is not in the fire, the fire is a basic element for the life of the human being...The problem is not the fire; the problem is not the conuco either, the problem is when the conuco of two or three hectares is burned and the fire comes out of the conuco and burns a thousand hectares of the forest,". Mayor Miguel Matany, First Commander of the INPARQUES Forest-firefighers, Venezuela

In the end, participants agreed that all types of knowledge and skill were valuable and indispensable, as well as on the importance of the joint construction of mutual trust, respect, and harmony (Figure 3).

"What is happening in this workshop is a historical fact. After many long efforts ... to demonstrate the ecological and cultural value of our traditional fire knowledge, we were able to advance [our cause] through new rules of the game for the three actors living in the Gran Sabana in Canaima National Park [Indigenous communities, government institutions, and scientists] with respect to fire management... We must all work equitably, in common wealth for the good of our society". Secretary of the Kavanayén captaincy and teacher of Kavanayén Technical Highschool (ETAK), former technician of Parupa Scientific Station, Gran Sabana, Venezuela

4.3.5. Lack of appropriate acknowledgement and hoarding of indigenous knowledge by Some Academics

Venezuelan Indigenous communities also expressed some mistrust and criticisms about particular academics' behavior in the CNP, since in the past, some of them had collected and extracted information without acknowledging their contribution, neither returning or sharing the research findings with them.

\subsection{New Approaches to an Intercultural and Participative Fire Governance}

In order to promote a consensus about what should be the ideal situation and the objectives to be pursued for fire management in the region, all participants, organized by country (i.e., Venezuela, 
Brazil, and Guyana), regardless of their affiliation or identity, engaged in a collective discussion to build proposals to overcome their concerns and move beyond current problematic situations.

The participants agreed on the importance of knowledge and action articulation among all institutions and communities involved in fire management.

They considered that the old paradigm of "no burning" or fire exclusion should be abandoned in favor of a holistic and participative model of fire management. Joint and coordinated action plans that include communities, as well as technical and academic institutions, should address legal issues, along with the exchange of different types of knowledge, techniques, and experiences about fire control and management. Different types of knowledge (i.e., traditional, technical, and academic) should be considered to fully understand fire behavior in different conditions, and to develop fire management plans.

"We identify, as the technical body of our organization, that we need better training to approach Indigenous communities, to know how to introduce ourselves into communities with the necessary respect so that it does not interfere in decisions, so that it does not interfere in the structure of communities, so that it does not cause divisions, and instead, it becomes an element of fusion and congregation. So, we see the need to have better training for our technical staff of our organization through participatory methodologies where it adds value to that reality". Firefighter, IBAMA/PREVFOGO

Community members highlighted the importance of dialogue and mutual agreement for better conservation of the natural protected areas they inhabit. Therefore, they believe that an ideal situation should allow a respectful exchange of ideas and points of view towards a truly participatory and intercultural fire management approach. Traditional Indigenous fire knowledge and new scientific findings on fire management should be widely disseminated, including government and academic spheres.

“... To embrace Indigenous ancestral knowledge of fire, scholar knowledge, and the technical capacities of institutions in the construction of a new fire management plan in the Pemón Indigenous territory. Based on the ancestral knowledge of fire management, we are going to unite all types of knowledge in order to generate a new fire management model for the region ... ". Pemón Taurepang Indigenous firefighter from CORPOELEC

Pemón Indigenous participants expressed that they expect academics to take responsibilities for monitoring and translating the significance of environment and social changes (climate change, etc.) so that fire management plans can be permanently adjusted and improved. Academics agreed on this, stressing that instead of acknowledging different counterparts' opinions, true inclusion and horizontal exchanges should be guaranteed in the process of building up a new fire management paradigm.

"We want a dialogue between institutions and communities in order to validate traditional knowledge and achieve fire management. Scientists could help us to validate that knowledge. Dialogue is going to help accomplish the goal of proper fire management". Pemón Arekuna Indigenous representative from Kavanayén, Gran Sabana

All participants agreed on the idea that prescribed fire practices represent an opportunity for common action, since they have been used traditionally by Indigenous people as well as firefighting technicians as a means to reduce and control the amount of flammable material to prevent wildfire occurrence. Therefore, it would be useful to reveal the value of traditional knowledge on fire use and management and develop a shared base of fire knowledge.

Open-minded approaches from institutional representatives eased the way for more respectful and sympathetic attitudes towards Indigenous fire practices, and for the recognition of the need to promote policy changes within institutions. This strategy was actually implemented by the Fire Department of INPARQUES, which was actively involved in previous processes of formal exchanges of knowledge with scholars undertaking participatory fire-related action research in CNP. 
"... We don't come to tell you not to burn; we come to burn with you, to participate with you in the burning so that it doesn't turn into a wildfire. For us, fire is one thing and wildfire is another thing, and you will never hear us anymore to say "no" to burn, what we don't want is more wildfires in the forests that give life to you and everyone else...". Mayor Miguel Matany, First Commander of the INPARQUES Forest-firefighters, Venezuela

Overcoming linguistic barriers and interpretations was also a major factor for reaching an understanding towards a common agreement in relation to fire co-management in Indigenous lands. Members of the Pemón community did not agree with the word "reconocer el conocimiento indígena" (acknowledge Indigenous knowledge), since they considered that the word "acknowledge" implies the existence of someone superior that gives his/her approval to another's opinion, instead of assuring mutual understanding and equal value for participants knowledge. After a long discussion, they offered the term "inclusión del conocimiento indígena" (embrace Indigenous knowledge) together with other types of knowledge.

There was also a shared consideration about the need to create a common "language" for intercultural understanding, whereby terms have the same meaning for everybody. That was the case for preferring to use the terms "academics" or "scholars" (académicos, in Spanish) instead of scientists to refer to researchers, since the Indigenous participants consider themselves as true scientists as well, although their training occurs in the natural environment they inhabit, where they learn their knowledge from the elders.

Some concerns arose in relation to the leadership, roles, and responsibilities that communities could undertake in relation to fire management and control activities. Indigenous participants insisted on being involved as equal partners in all the stages and decisions related to fire management.

After long discussions and easing of tensions, the directives and representatives of the different institutions approved to support and respect the agreements reached during the workshop and to develop a new paradigm of fire management based on the integration and collaboration of Indigenous communities, academics, and institutions ${ }^{7}$.

"Let us all unite, institutions and Indigenous communities with our knowledge. We are ancestral firefighters, we know how to handle fire, and how to walk the roads, so that we burn. It is time for us all to unite: institutions, Indigenous people, and scientists to look for the solution we are talking about. We are willing to collaborate with the institutions, and the institutions are willing to collaborate with us; but let's do it without restrictions, because the institutions are arrogant many times. You can't do that, since in the life of the Indigenous that [arrogance] never existed, and we don't want that. What we want is to be united in the work, to find the solution". Head of the Elder's Council, Pemón Arekuna Indigenous community leader of Kavanayén for over 20 years, and former firefighter of CORPOELEC, Gran Sabana, Venezuela

\section{Discussion}

The testimonies offered in this workshop by Indigenous participants from Venezuela, Brazil, and Guyana were extremely rich and exposed the holistic vision they have about human and environmental issues, which are tightly interlinked in their daily lives.

Indigenous discourses showed that, in spite of the many socio-cultural, demographic, land, and climatic changes they have experienced over time, the traditional use of fire is still a fundamental sustainable tool for their livelihoods, and a meaningful factor in their cultural identity and social cohesion. Indigenous Pemón, Makushi, and Wapishana peoples in the central Guiana Shield of South America, all maintain the controlled use of fire for agriculture, hunting, and fishing, among other

7 Details of specific plans and actions of each country can be seen in the first report: http://projectcobra.org/participatory-andintercultural-fire-management-network/ 
subsistence practices [4-9]. With very few local differences, these three groups of Indigenous cultures currently use similar fire management techniques to protect forests in the characteristic vegetation mosaic landscape they inhabit in the Guiana Shield. These findings suggest an effective historical cultural transmission of these Indigenous knowledge and practices [38,81], along generations and also among different Amerindian groups belonging to the Amerindian Caribbean and Arawak families. Local resource management carried out over thousands of years in this tropical region of South America [10-12,36,50,51,53] has been revealed to be effective in sustaining the coexistence of forest and savanna ecosystems in Indigenous territories.

On the other hand, firefighters', the PA administrator's, and participants' discourses revealed their commitment to serve a meaningful purpose in order to protect biodiversity and natural areas, although they were aware of the many difficulties and limitations they face to accomplish their tasks. They were open to embracing new approaches about fire management, whenever practical and academic evidence proved them useful; they also acknowledged the importance of working together with local Indigenous communities to achieve sustainable and efficient solutions.

Academics' discourses acknowledged the undesirable effects of the hegemonic policies that have historically stigmatized and marginalized Indigenous peoples from participation and decision making. They showed a respectful disposition to understand and make known Indigenous knowledge and practices. The organization of this and similar past events represents an example of the contribution from academics (workshop organizers) to the process of facilitating the integration of different perspectives and planning joint work.

The evidence and experiences shared at the meeting allowed the participants to: (a) acknowledge the importance and value of fire for ecosystems, humans culture, and survival; (b) accept new approaches and perceptions about fire ("fire as friend", "fire as a tool", "responsible and holistic use of fire", "management, planning, prevention, and control of fire", instead of "combat, suppression and exclusion of fire", "fire as enemy"); (c) acknowledge the value of traditional Indigenous understanding of fire for the long-term sustainability of ecosystems; and d) integrate and transcend different ways of knowing and understanding fire behavior and its impacts, in order to promote adequate adaptation responses to the effects of climate change in the region.

However, some doubts cast shadows over these optimistic outcomes. Considering the historical processes of the colonial times and the current national policies that have ignored traditional Indigenous systems of living, what is the future of these fire Indigenous practices? Indigenous participants expressed major concerns as to the current loss of traditional knowledge about fire uses and other traditional practices, as well as to the actual possibilities to apply them in their territories.

According to their testimonies, several factors seem to contribute to hinder the natural processes of cultural transmission of their traditional knowledge about fire within their own communities.

Among younger generations of Indigenous people, traditional practices are being replaced by Western ways of living; proper application of ancient methods remain a domain of the elders who received the ancestral Indigenous education. For example, very few Pemón youngsters show interest in learning the traditional cultural domains, whose active initiative and personal interest is a prerequisite to acquire this knowledge [25,82,83]. Since Caribbean and Arawak are cultures of oral transmission [38], this represents a serious threat to the survival of these cultures.

Along with the establishment of permanent settlements, schools have also become an important way of education and cultural transmission in Indigenous communities of Latin America, replacing orally transmitted cosmovisions and norms by written codex. Although these Indigenous schools are frequently bilingual, the teaching programs do not incorporate Indigenous knowledge and local forms of teaching, since their curricula have standardized contents which are designed by the national Ministries of Education [82]. Thus, Indigenous students learn Western culture in their mother tongues [25]. Some authors have previously noticed that learning in small-scale societies is typically experimental: it occurs over time, through hands-on experience (experiments and practices), play and direct observations of the adult's performance, which is unlikely to occur in schools $[31,35,84,85]$. 
The religious influence of the early Catholic and other Christian missionaries, who were established in these Indigenous communities during the 19th and 20th centuries, to develop different educational initiatives, has interfered with traditional oral transmission to new generations of traditional Indigenous culture and beliefs [82]. Traditionally, the native's spirituality and source of knowledge was conditioned by the belief in the many spirits of nature (polytheism) $[35,86,87]$, but in the modern phase, some Indigenous peoples have converted to the monotheistic religion of Christianity [19]. In the case of Pemón, for instance, the teaching of traditional fire practices is associated with the myth of Makunaima, known as the "father of all Pemón Indigenous", an ancestral figure representing goodness and wisdom, who gave Pemón peoples the legacy to set and handle fire in a responsible and harmless way [25].

The loss of Indigenous rights of ownership and management over their territories and the subsequent forced migration in search of new opportunities of subsistence are considered one of the main reasons for generating acculturation processes in Indigenous communities [88]. Since Indigenous societies are very closely connected to their environment [37], the loss of contact with their native habitat affects them deeply. For Indigenous peoples, the acquisition of rights over their own territories has represented a long historical struggle that extends until the present [57]. For example, the official reconstitution process of Raposa Serra do Sol, in Brazil, and the allocation of land rights to the Makushi took a period of 90 years, from 1917 to 2007 [89], and this is now threatened by the anti-Indigenous rhetoric of the current government ${ }^{8}$.

Indigenous communities that inhabit protected areas suffer the effects of official policies intended to protect and conserve biodiversity which are enforced by PA managers, who generally ignore or go against traditional Indigenous practices [62,90]. Likewise, in many Latin American countries, the declaration of protected areas implies the eviction of all their inhabitants, even when these areas represent the ancestral territories of Indigenous communities. Although the implementation of MIF in PAs represents a significant advance for fire management in Brazil, burning vegetation outside reserves is not yet legally permitted [63] and the presence of Indigenous people in PAs is also forbidden or restricted [58]. This has generated conflicts concerning Indigenous rights of occupation in these Pas, as well as the application of late burns and other traditional practices of fire and natural resource management $[9,28,58]$.

Considering the obvious process of acculturation that Amerindian peoples experience and the limitations to implement their traditional practices, there is an urgent need to design and put into effect a new intercultural fire management (IFM) policy that restores and strengthens the mechanisms of transmission of their own culture within the Indigenous communities. These actions are vital, since the grandparents, who are the main holders of this knowledge, are dying. Likewise, we believe that Indigenous cultural restoration integrity is a necessary process for ecological restoration integrity and Indigenous people's resilience. The construction of an inclusive process that embraces nature and cultural interrelationships and which involves all sectors of society, such as Indigenous communities, is an imperative $[24,25,27,28,31,35,86,87,90,91]$.

The development of IFM policies, based on the recognition of the value of Indigenous knowledge for fire management, is an important step towards a paradigm shift in fire management. Examples of these important initiatives towards IFM implementation are represented by Australia and Brazil $[9,27,28$, $57,63,92-94]$. However, a real process to ensure interculturality and active participation of Indigenous communities still represents a challenge. These IFM experiences run the risk of incorporating only the utilitarian value of Indigenous knowledge for the implementation of early burns in savanna areas to reduce fuel and avoid higher intensity burns at the end of the drought. These new forms of management will not be effective or sustainable if Indigenous culture is not strengthened and Indigenous practices are not actively incorporated $[25,27,28,31,35,86,87,95]$. Otherwise, this approach

8 https://www.theguardian.com/world/2019/mar/04/we-are-fighting-brazils-Indigenous-groups-unite-to-protect-theirland 
will lead to the loss of the rich and diverse legacy of Indigenous fire practices that promote diversity and ecosystems' health in a wide array of environments.

Intercultural and participative management also faces the challenge of integrating Indigenous knowledge with scientific-academic knowledge, using the capacities and expertise of institutions to promote sounded and unprejudiced participative research over socio-environmental conditions that revolve around Indigenous fire management and application $[24,25,28,29,31,34,35,86,87,95]$.

Another relevant question that emerged during the discussion was: How do Indigenous people cope and adapt to climate change? In the workshop, Indigenous participants mentioned that they have observed environmental signs of changing climatic patterns, such as extended dry seasons, higher environmental temperatures, and unexpected changes in weather (rains during dry season or dry periods during wet seasons) that they relate to a higher frequency, spread, and severity of wildfires in their lands $[18,23,29]$. Representatives of firefighters' institutions and Indigenous communities both acknowledged the damage and impact caused by these big wildfires or "megafires" and the difficulties in coping with them (Figure 3, see also footnote 1). Academics pointed out that the Indigenous fire management strategy, which reduces the accumulation of combustible material in fire-prone environments, can contribute to preventing the occurrence and spread of large fires to the edge zones and tropical forests, and be more effective than expensive technical approaches to combat wildfires, especially in the face of increasingly severe climate change scenarios $[5,10,18,23,25,29,33]$. Under increasing temperature scenarios, the fire risk also increases with any accident or loss of control during traditional fire practices for agriculture, hunting, and other purposes. In this sense, the maintenance of Indigenous traditional knowledge and the promotion of Indigenous best practices of the use of fire is essential to reduce the spread of fire without control, especially in conditions of greater vegetation vulnerability. Indigenous people also expressed the importance of the support of firefighters and academics to plan safer burning conditions and the acquisition of training and tools to prevent the spread of uncontrolled fires. All participants agreed on the adaptive value of working and learning together to develop a new fire management paradigm that integrates the efforts, knowledge, and capabilities of Indigenous people with governmental institutions and academics $[29,34,96]$.

In the face of all these challenges, is it possible to integrate Indigenous fire knowledge into fire management policies in the region? Reaching the desirable goal of an intercultural and participative fire management demands continuous efforts through time, in order to build up mutual trust and joint working spaces [25,28,31,35,70]. The previous experiences of Venezuela's, Brazil's, and Guyana's workshop participants revealed different degrees of advance in this respect. In the case of Venezuela, the long-term controlled burning experiment and the intercultural workshops undertaken in Canaima since year 1999 [5,19,25,26,76] helped academic Venezuelan researchers, Pemón communities, and firefighters to understand the features of Indigenous burnings and also that Indigenous patch mosaic burning in savanna areas actually protect nearby forests $[5,10,19,25]$. On the contrary, savanna areas excluded from fire for many years accumulate very dangerous dead biomass converting them into very vulnerable areas for the spread of catastrophic wildfires. Thus, clarifying the differences between traditional Indigenous practices, controlled burns, and wildfires [5,10,19,25]. As a result, early cooperative activities were promoted, and, for instance, PCIV Indigenous firefighters, who understood both the traditional uses of fire as well as Western fire combat techniques, started to offer support to communities to assure the success of controlled fires during Indigenous conuco practices instead of forbidding them $[76,97]$. These experiences eased the way towards the definition of Venezuela's ideal fire management situation based on the integration of Indigenous, academic, and technical knowledge.

Brazil's and Guyana's groups presentations focused on identifying activities that could contribute to greater intercultural and participatory fire governance. Indigenous participants from both countries highlighted the importance of generating actions to reinforce and recover Indigenous traditional knowledge and practices, as well as their own internal organization. In the case of Brazil, the lists of actions were presented separately by Indigenous and institutional representatives. This last group expressed the need to integrate several national institutions such as environmental agencies and 
institutions: PREVFOGO-IBAMA (Instituto Brasileiro do Meio Ambiente e dos Recursos Naturais Renováveis), SISNAMA (Sistema Nacional do Meio Ambiente), PBA (Plano Básico Ambiental) with the ones in charge on Indigenous issues: i.e. FUNAI (Fundação Nacional do Índio), to generate joint actions and advance in the implementation of a new governance for participatory fire management in Brazil. In addition to improving performance, they consider that it is very important to gather human resources and efforts due to the growing cuts of funds destined to government institutions for fire management programs. Likewise, it represents an alternative to distribute the high costs of organizing brigades and other professionals and their mobilization for implementation of MIF programs in a country as extensive as Brazil (see footnote 1). The Wapishana and Macuxi communities in Guyana also raised the proposal to obtain international funds from different NGOs to continue regional integration activities, informing about the role of international actors in this country where public institutions are of more recent creation.

All stakeholders and Indigenous representatives involved with fire management in protected areas in the Guiana Shield area were disposed to reach an agreement for a sustainable solution to fire conflicts in the area, since official fire exclusion policies and practices currently applied do not fulfil their expectations. While scholars and official representatives of environmental management institutions recognized the inefficiency of the 'zero fire' policy as a conservation strategy, Indigenous participants claimed their inherent right to decide how and when to use fire. Pemón participants demanded equal participation (co-management) in policy development, decision making, and planning processes related to fire management.

Putting into practice a shared and co-responsible leadership is perhaps the major key issue in order to achieve a truly intercultural policy $[27,28,31,35,98]$. Fire management decisions should be shared between the three groups composed of stakeholders and Indigenous peoples correspondingly. It is expected that this change will counterbalance the dominant discourse imposed by the institutions and recognize Indigenous knowledge about fire management as valid $[31,35,87,98]$. The challenge is not only to integrate knowledge but also to implement practices with active, equitable, and representative participation; this could be achieved by carrying out common projects. This is an important step towards overcoming the complex legacies of social, economic, political, and environmental realities, and patterns of advantage, disadvantage, and imbalanced power of the different cultural groups in Indigenous territories [33,70,95,99].

Finally, during the last day of the workshop important joint actions were unanimously decided such as the creation of a "Participatory and Intercultural Fire Management Network" and a joint declaration (Box 1), that served the purpose of making visible to the rest of Indigenous communities, government authorities, and academics the agreements reached, expressing the commitment of all stakeholders from Venezuela, Brazil, and Guyana to keep on working together towards Indigenous fire management legitimization and reinforcement, as well as the promotion of a sustainable intercultural fire policy in the region.

\section{Conclusions}

The Parupa workshop offered a unique occasion for different stakeholders from Venezuela, Brazil, and Guyana to exchange multiple perspectives and experiences about fire management in the Guiana region. This event allowed distant Pemón, Wapishana, and Macuxi Indigenous communities, of the same ethnic origin (Caribbean and Arawak) but separated geographically and historically, to reunite and recognize that they still maintain a strong common cultural bond, with similar practices and knowledge about the use of fire. Likewise, this encounter helped them to recognize that they struggle alike to maintain their identity and culture, a fact that worked as an excellent impelling driver in the search for solutions and alliances that help them face fire management challenges together.

In spite of the worries expressed by the different groups of participants, a shared willingness to go beyond bitter experiences of the past emerged during the meeting, giving way to a disposition to 
work and learn together in order to build a participatory and intercultural fire management policy that integrates Indigenous knowledge together with scientific and institutional knowledge and skills.

Some important lessons were achieved from the intercultural fire management workshop in Parupa, Gran Sabana, Venezuela:

1. The process of facilitation by academics requires proactive responses and some "out of the box thinking" to overcome tension and antagonism proper of any intercultural building process. A respectful attitude towards different cosmovisions can open up opportunities to identify convergent points and overcome historical disagreements among different stakeholders in order to find adaptive, sustainable, inclusive, and socially just solution to common challenges.

2. The use of appropriate language was a key element to reach an agreement about intercultural fire management in accordance to previous findings in the process of natural resource planning with Indigenous people in different geographical contexts [31,35,81,82,86,87].

3. The need to face a new challenge of adapting to the adverse conditions generated by climate change can be a key point of convergence since all stakeholders and Indigenous representatives recognized its socio-ecological disruptive impact on Indigenous and protected territories. The visualization of a common objective and benefits for all parties contributed to formulate alliances and joint actions of cooperation among all actors within and amid all countries.

4. Building up long-term relationships with Indigenous communities, is an indispensable requirement to achieve mutual trust and convening power for joint actions, as well as the establishment of lasting agreements. This involves a paradigm shift in governance policies in state agencies and research centers that usually work with specific and practical projects' objectives, aimed to achieve short-term results.

5. In addition to the integration of Indigenous, scientific, and technical knowledge, a legitimate and sustainable management of fire in territories inhabited by Indigenous peoples must guarantee the active and equitable participation and joint learning of all actors, safeguarding their culture and allowing the implementation of their traditional Indigenous practices. In other words, fire management must be participatory and intercultural and must be developed within a framework of social justice, respecting the sovereignty and cultural integrity of Indigenous peoples. It is not enough to recognize the existence of multiple cultures (multiculturality), instead different powers of public dimensions should guarantee equitable conditions of participation in the dialogue between these cultures (interculturality).

6. The challenge of interculturality is that different stakeholders manage to coordinate their actions instead of promoting isolated initiatives, so that reciprocal tendencies equilibrate and balance each other, creating a common space of coexistence, that is an "intercultural interface" of institutions working on environmental management and governance. Without the promotion of these conditions, which also aims at the construction of inclusive identities, the power imbalances and the domination of the hegemonic culture over the minority ones will still prevail.

This new intercultural interface represents an opportunity to promote dialogue and exchanges among stakeholders, Indigenous peoples, and countries in order to find more just and sustainable ways of environment management and governance. In Venezuela and Brazil, significant progress has already been made transforming a fire suppression policy into the development of new national integrated fire management plans including formal agreements between communities and governmental institutions, and proposals for their incorporation into plans for adapting to the effects of climate change. 
Box 1. Declaration on participatory and intercultural fire management.

At the 2016 Parupa workshop, the following declaration was co-developed by the sixty Indigenous, scientific, and institutional participants from Brazil, Venezuela, and Guyana:

We, members of the Participatory and Intercultural Fire Management Network, believe that Indigenous fire management must be integrated into the management of the territories in which Indigenous people live and make their livelihoods, using ancestral, traditional, and adaptive Indigenous fire knowledge supported by scientific/academic and institutional partners.

- $\quad$ Respect Indigenous knowledge and practices relating to the use of fire.

- $\quad$ Promote the empowerment of Indigenous communities and their active participation in decision-making, and allow communities more autonomy with respect to policies, including the leading of projects (or initiatives) for fire management.

- Encourage institutions to support national and international level funding for Indigenous fire management, for example to reduce deforestation and limit carbon emissions.

- $\quad$ Promote the use of visual modes of communication for raising awareness and reinforcing traditional fire practices.

Author Contributions: Conceptualization, B.B. and J.M.; Data curation, B.B., J.M. and A.M.; Formal analysis, B.B., J.M. and A.M.; Funding acquisition, B.B. and J.M.; Investigation, B.B., J.M., A.M. and A.B.; Methodology, B.B., J.M. and A.B.; Project administration, B.B. and J.M.; Resources, B.B., J.M. and A.B.; Supervision, B.B. and J.M.; Validation, B.B., J.M. and A.M.; Visualization, B.B., J.M. and A.M.; Writing-original draft, B.B.; Writing-review and editing, B.B., J.M., A.M. and A.B.

Funding: This research was funded by the British Academy International Partnership and Mobility Scheme (Ref. PM130370) and Venezuelan FONACIT Apök Project (Ref.2011000376, “Bases ecológicas y conocimiento tradicional Pemón del fuego: Soluciones locales para problemas globales del cambio climático").

Acknowledgments: We thank all the participants from Venezuela, Brazil and Guyana that attended to the workshop in Parupa Scientific Station (CVG), Gran Sabana, Canaima National Park, Venezuela. We would like to express our gratitude to: Elizabeth Rivera, Eduardo Zambrano, Sofia Marín from Universidad Simón Bolívar, Presidency of INPARQUES and its firefighters, particularly to Mayor Miguel Matany, and lieutenants Enrique Meza and Paul Tietz ${ }^{\dagger}$, the Staff of Parupa Scientific Station, specially to Héctor Rodríguez, Rosa Hernao, José Gregorio León and Humberto Chaní for their noteworthy logistic support, collaboration and assistance in the organization of the workshop, as well as to the Biology Division of the Simón Bolivar University for their support in facilitating transportation to Canaima National Park. We wish to extend our particular appreciation to the Pemón Indigenous Kavanayén and Iworiwo communities for their hospitality and warm attention during the reception given to the workshop participants. The authors also would like to thank to Jonathan Rodríguez and Roberto Rivera for elaborating the map of Indigenous locations in Central Guiana Shield, Mike Smith and Howard Takiff for their revision of some English terms and Rosalba Gómez for her valuable and numerous helpful comments to improve the drafts of the manuscript. We are grateful to the two anonymous referees and the Fire Journal Academic Editor for contributing to the development of this article with constructive, insightful and very helpful suggestions. This paper is dedicated to the memory of Pemón's Indigenous grandparents: Irene Basabe ${ }^{\dagger}$, Antonio Aguirre ${ }^{\dagger}$, Luis Rodríguez ${ }^{\dagger}$ and Inocencio Gil Lanz ${ }^{\dagger}$, who generously contributed to keep alive and teach to the young people, the ancestral Indigenous knowledge and practices, and Lieutenant Paul Tietz ${ }^{\dagger}$, Chief of the Forest Fire Station Salamanca, who, with his conviction about the value of integration of knowledge with the communities allowed to advance towards the intercultural management of fire in Venezuela.

Conflicts of Interest: The authors declare no conflict of interest. The funders had no role in the design of the study; in the collection, analyses, or interpretation of data; in the writing of the manuscript, and in the decision to publish the results. 


\section{Appendix A}

Table A1. List of participating organizations and institutions in the first workshop of Participatory and Intercultural Fire Management Network.

\begin{tabular}{|c|c|}
\hline \multicolumn{2}{|c|}{ INDIGENOUS ORGANIZATIONS } \\
\hline INDIGENOUS GROUPS & PARTICIPATING ORGANIZATIONS \\
\hline $\begin{array}{l}\text { Arekuna, Taurepang and Kamarakoto } \\
\text { Pemón people }{ }^{1}\end{array}$ & $\begin{array}{l}\text { (1) Council of Elders, Pemón Indigenous Community, Santa Teresita } \\
\text { de Kavanayén, Gran Sabana, Canaima National Park, Venezuela. } \\
\text { (2) Captaincy of Santa Teresita de Kavanayén, Gran Sabana, } \\
\text { Canaima National Park, Venezuela. } \\
\text { (3) Agricultural Technical School (ETAK), Pemón Arekuna } \\
\text { Indigenous Community, Santa Teresita de Kavanayén, Gran Sabana, } \\
\text { Venezuela. }\end{array}$ \\
\hline Ye'kuana people $^{2}$ & $\begin{array}{l}\text { (4) National Indigenous Experimental University of Tauca (UNEIT), } \\
\text { Venezuela. }\end{array}$ \\
\hline Macuxi people $^{3}$ & $\begin{array}{l}\text { (5) Conselho Indígena de Roraima (CIR), Comunidade Maturuca, } \\
\text { Etnoregião Serras, Terra Indigena Raposa Serra do Sol, Roraima, } \\
\text { Brazil. } \\
\text { (6) Conselho Indigena de Roraima (CIR), Comunidade Normandia, } \\
\text { Etnoregião Raposa, Terra Indigena Raposa Serra do Sol, Roraima, } \\
\text { Brazil. } \\
\text { (7) North Rupununi District Development Board (NRDDB), Guyana. }\end{array}$ \\
\hline Wapishana people ${ }^{4}$ & $\begin{array}{c}\text { (8) South Central Peoples Development Association (SCPDA), } \\
\text { Guyana } \\
\text { (9) Conselho Indigena de Roraima CIR, Comunidade e Terra } \\
\text { Indigena Malacacheta, Etnoregião Serra da Lua, Roraima, Brazil. } \\
\text { (10) Conselho Indigena de Roraima (CIR), Comunidade Lage, } \\
\text { Etnoregião Serras da Lua, Cantá, Roraima, Brazil. }\end{array}$ \\
\hline \multirow[t]{2}{*}{ Xingu people $^{5}$} & (11) Institute Raoni (IR), Brazil. \\
\hline & GOVERNMENTAL INSTITUTIONS \\
\hline INSTITUTIONS' TYPES & PARTICIPATING INSTITUTIONS \\
\hline Firefighters' Institutions & $\begin{array}{l}\text { (12) Bomberos Forestales del Intituto Nacional de Parques. } \\
\text { Ministerio del Poder Popular para el Ecosocialismo y Aguas, } \\
\text { Venezuela. * } \\
\text { (13) Programa de Control de Incendios, Corporación Eléctrica } \\
\text { Nacional S.A. (CORPOELEC), Ministerio del Poder Popular para la } \\
\text { Energía Eléctrica, Venezuela. } \\
\text { (14) Brigada de Bomberos Forestales "Ataque Inicial Carlos Todd", } \\
\text { Corporación Eléctrica Nacional S.A. (CORPOELEC), Ministro del } \\
\text { Poder Popular para la Energía Eléctrica, Venezuela. } \\
\text { (15) Prevfogo, Instituto Brasileiro do Meio Ambiente e dos Recursos } \\
\text { Naturais Renováveis (IBAMA), Ministério do Meio Ambiente, Brazil. }\end{array}$ \\
\hline Park Administration & $\begin{array}{l}\text { (16) Dirección General, Intituto Nacional de Parques. Ministerio del } \\
\text { Poder Popular para el Ecosocialismo y Aguas, Venezuela. }\end{array}$ \\
\hline \multirow[t]{2}{*}{ Pro-Indigenous Institutions } & (17) Fundação Nacional do Índio (FUNAI), Brazil. \\
\hline & ACADEMIC INSTITUTIONS \\
\hline INSTITUTIONS' TYPES & PARTICIPATING INSTITUTIONS \\
\hline
\end{tabular}

(18) Universidad Simón Bolívar (USB), Venezuela. *

(19) Royal Holloway University of London (RHUL), United Kingdom. *

(20) The Open University (OU), United Kingdom. *

Universities

(21) Instituto de Geografía y Desarrollo Regional. Universidad Central de Venezuela (UCV), Venezuela.

(22) Instituto de Biología Experimental, Universidad Central de Venezuela.

(23) Universidad Bolivariana de Venezuela (UBV).

(24) United Nations University Traditional Knowledge Initiative (UNU), Japan. 
Table A1. Cont.

\begin{tabular}{|c|}
\hline ACADEMIC INSTITUTIONS \\
\hline PARTICIPATING INSTITUTIONS \\
\hline $\begin{array}{l}\text { (25) Instituto Venezolano de Investigaciones Científicas (IVIC), } \\
\text { Venezuela. } \\
\text { (26) Instituto Nacional de Pesquisas da Amazônia (INPA), Brazil. }\end{array}$ \\
\hline $\begin{array}{l}\text { (27) Scientific Station Parupa, Corporación Venezolana de Guayana } \\
\text { (CVG), Venezuela. * }\end{array}$ \\
\hline 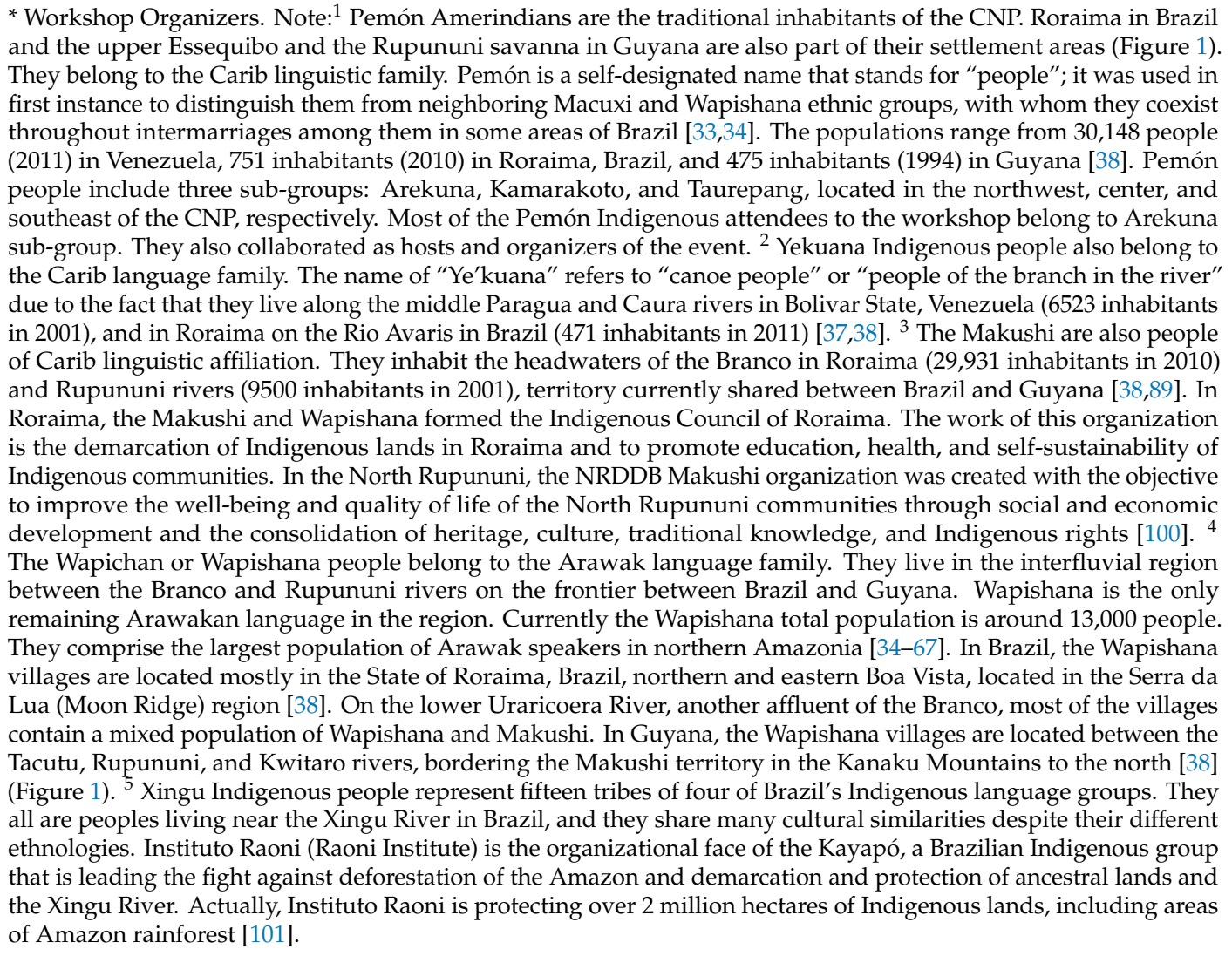 \\
\hline
\end{tabular}

\section{References}

1. Bowman, D. Wildfire science is at a loss for comprehensive data. Nature 2018, 560, 7. [CrossRef] [PubMed]

2. Chuvieco, E.; Lizundia-Loiola, J.; Pettinari, M.; Ramo, R.; Padilla, M.; Tansey, K.; Mouillot, F.; Laurent, P.; Storm, T.; Heil, A.; et al. Generation and analysis of a new global burned area product based on MODIS 250 reflectance bands and thermal anomalies. Earth Syst. Sci. Data 2018, 10, 2015-2031. [CrossRef]

3. Tollefson, J. Enormous wildfires spark scramble to improve fire models. Nature 2018, 561, 16-17. [CrossRef] [PubMed]

4. Mistry, J.; Berardi, A.; Andrade, V.; Leonardos, O. Indigenous fire management in the Cerrado of Brazil: The case of the Krahô of Tocantıns. Hum. Ecol. 2005, 33, 365-386. [CrossRef]

5. Bilbao, B.A.; Leal, A.V.; Méndez, C.L. Indigenous Use of Fire and Forest Loss in Canaima National Park, Venezuela. Assessment of and Tools for Alternative Strategies of Fire Management in Pemón Indigenous Lands. Hum. Ecol. 2010, 38, 663-673. [CrossRef]

6. Rodríguez, I.; La Rose, A.P.; Sharpe, C.J. A study of the use of fire by Amerindian communities in South Rupununi, Guyana, with recommendations for sustainable land management. In Study Prepared for the South Central and South Rupununi District Toshaos Councils; South Central Peoples Development Association (SCPDA), Forest Peoples Programme: Norwich, UK, 2011.

7. Huffman, M.R. The many elements of traditional fire knowledge: Synthesis, classification, and aids to cross-cultural problem solving in fire dependent systems around the world. Ecol. Soc. 2013, 18. [CrossRef] 
8. Welch, J.R. Xavante Ritual Hunting: Anthropogenic Fire, Reciprocity, and Collective Landscape Management in the Brazilian Cerrado. Hum. Ecol. 2014, 42, 47-59. [CrossRef]

9. Eloy, L.; Schmidt, I.B.; Borges, S.L.; Ferreira, M.C.; dos Santos, A.T. Seasonal fire management by traditional cattle ranchers prevents the spread of wildfire in the Brazilian Cerrado. Ambio 2018, 48, 890-899. [CrossRef] [PubMed]

10. Russell-Smith, J.; Monagle, C.; Jacobsohn, M.; Beatty, R.; Bilbao, B.A.; Millán, A.; Vessuri, H.; Sánchez-Rose, I. Can savanna burning projects deliver measurable greenhouse emissions reductions and sustainable livelihood opportunities in fire-prone settings? Clim. Chang. 2013, 140, 47-61. [CrossRef]

11. Trauernicht, C.; Brook, B.W.; Murphy, B.P.; Williamson, G.J.; Bowman, D.M.J.S. Local and global pyrogeographic evidence that Indigenous fire management creates pyrodiversity. Ecol. Evol. 2015, 5, 1908-1918. [CrossRef] [PubMed]

12. Roos, C.I.; Scott, A.C.; Belcher, C.M.; Chaloner, W.G.; Aylen, J.; Bliege Bird, R.; Coughlan, M.R.; Johnson, B.R.; Johnston, F.H.; McMorrow, J.; et al. Living on a flammable planet: Interdisciplinary, cross-scalar and varied cultural lessons, prospects and challenges. Philos. Trans. R. Soc. B Biol. Sci. 2016, 371, 20150469. [CrossRef] [PubMed]

13. Dezzeo, N.; Chacón, N. Carbon and nutrients lose in aboveground biomass along a fire induced forest-Savanna gradient in the Gran Sabana, southern Venezuela. For. Ecol. Manag. 2005, 209, 343-352. [CrossRef]

14. Laris, P.; Wardell, D.A. Good, bad or 'necessary evil'? Reinterpreting the colonial burning experiments in the savanna landscapes of West Africa. Geogr. J. 2006, 172, 271-290. [CrossRef]

15. Rull, V.; Montoya, E.; Vegas-Vilarr!ubia, T.; Ballersteros, T. New insights on palaeofires and savannisation in northern South America. Quat. Sci. Rev. 2015, 122, 158-165. [CrossRef]

16. Barradas, A.C.S. A gestão do fogo na Estação Ecológica Serra Geral do Tocantins, Brasil (Fire management at the Serra Geral of Tocantins Ecological Station, Brazil); Escola Nacional de Botânica/Jardim Botânico do Rio de Janeiro: Rio de Janeiro, Brazil, 2017. (In Portuguese)

17. Pereira, A.C.J.; Oliveira, S.L.J.; Pereira, J.M.C.; Turkman, M.A.A. Modelling Fire Frequency in a Cerrado Savanna Protected Area. PLoS ONE 2014, 9, e102380. [CrossRef] [PubMed]

18. Fidelis, A.; Alvarado, S.; Barradas, A.; Pivello, V. The Year 2017: Megafires and Management in the Cerrado. Fire 2018, 1, 49. [CrossRef]

19. Bilbao, B.; Leal, A.; Méndez, C.; Delgado-Cartay, M.D. The role of fire on vegetation dynamics of upland savannas of the Venezuelan Guayana. In Tropical Fire Ecology: Climate Change, Land Use and Ecosystem Dynamics; Cochrane, M.A., Ed.; Springer: Heidelberg, Germany, 2009; pp. 451-480.

20. McDaniel, J.; Kennard, D.; Fuentes, A. Smokey the Tapir: Traditional Fire Knowledge and Fire Prevention Campaigns in Lowland Bolivia. Soc. Nat. Resour. 2005, 18, 921-931. [CrossRef]

21. Sorrensen, C. Potential hazards of land policy: Conservation, rural development and fire use in the Brazilian Amazon. Land Use Policy 2009, 26, 782-791. [CrossRef]

22. Carmenta, R.; Vermeylen, S.; Parry, L.; Barlow, J. Shifting Cultivation and Fire Policy: Insights from the Brazilian Amazon. Hum. Ecol. 2013, 41, 603-614. [CrossRef]

23. International Union of Forest Research Organizations (IUFRO). Global Fire Challenges in a Warming World; Robinne, F.-N., Burns, J., Kant, P., de Groot, B., Flannigan, M.D., Kleine, M., Wotton, D.M., Eds.; Occasional Paper 2018; IUFRO: Vienna, Austria, 2018.

24. Mistry, J.; Berardi, A. Bridging Indigenous and scientific knowledge. Science 2016, 352, 1274-1275. [CrossRef]

25. Bilbao, B.; Leal, A.; Pedraza, E.; Rosales, J.; Martın, S.; Millan, A.; Salazar-Gascón, R.; Chani, H. Chureta ru to pomupok: Integration of Indigenous and ecological knowledge for the restoration of degraded environments. In Beyond Restoration Ecology: Social Perspectives in Latin America and the Caribbean; Ceccon, E., Pérez, D.R., Eds.; Vazquez Mazzini Editores: Buenos Aires, Argentina, 2017; pp. 331-353.

26. Rodríguez, I.; Sletto, B.; Bilbao, B.; Sanchez-Rose, I.; Leal, A. Speaking of fire: Reflexive governance in landscapes of social change and shifting local identities. J. Environ. Policy Plan. 2013, 15, 689-703. [CrossRef]

27. Eloy, L.; Bilbao, B.A.; Mistry, J.; Schmidt, I. From fire suppression to fire management: Advances and resistances to changes in fire policy in the savannas of Brazil and Venezuela. Geogr. J. 2018, 185, 10-22. [CrossRef]

28. Mistry, J.; Schmidt, I.B.; Eloy, L.; Bilbao, B.A. New perspectives in fire management in South American savannas: The importance of intercultural governance. Ambio 2018, 48, 172-179. [CrossRef] [PubMed] 
29. David, A. Partnerships Forged in Fire: With Wildfires Becoming more Deadly Worldwide, Fire Management Agencies and Traditional Peoples are Combining Their Expertise to Reduce the Risk of Catastrophic Landscape Fires and Support Cultural Practices; Current Perspective Report; PRISMA Foundation: San Salvador, El Salvador, 2018; pp. $19-75$.

30. Cash, D.W.; Clark, W.C.; Alcock, F.; Dickson, N.M.; Eckley, N.; Guston, D.H.; Jäger, J.; Mitchell, R.B. Knowledge systems for sustainable development. Proc. Natl. Acad. Sci. USA 2003, 100, 8086-8091. [CrossRef] [PubMed]

31. Bohensky, E.L.; Maru, Y. Indigenous Knowledge, Science, and Resilience: What Have We Learned from a Decade of International Literature on "Integration"? Ecol. Soc. 2011, 16. [CrossRef]

32. Hegger, D.; Lamers, M.; Van Zeijl-Rozema, A.; Dieperink, C. Conceptualising joint knowledge production in regional climate change adaptation projects: Success conditions and levers for action. Environ. Sci. Policy 2012, 18, 52-65. [CrossRef]

33. Bilbao, B.; Holländer, M.; Koim, N.; Longoli, S.P.; Schielmann, S.; Stöber, S. Discovering the Cultures of Resilience: Promoting the contributions of traditional livelihoods to climate change mitigation and adaptation and global sustainable development. In Briefing paper. In Proceedings of the Impacts World 2017 Conference, Potsdam, Germany, 11-13 October 2017.

34. Nkoana, E.M.; Verbruggen, A.; Hugé, J. Climate Change Adaptation Tools at the Community Level: An Integrated Literature Review. Sustainability 2018, 10, 796. [CrossRef]

35. Ban, N.C.; Frid, A.; Reid, M.; Edgar, B.; Shaw, D.; Siwallace, P. Incorporate Indigenous perspectives for impactful research and effective management. Nat. Ecol. Evol. 2018, 2, 1680-1683. [CrossRef] [PubMed]

36. Mistry, J.; Bilbao, B.A.; Berardi, A. Community owned solutions for fire management in tropical ecosystems: Case studies from Indigenous communities of South America. Philos. Trans. R. Soc. Lond. B Biol. Sci. 2016, 371. [CrossRef]

37. Huber, O.; Zent, S. Indigenous people and vegetation in the Venezuelan Guayana: Some ecological consideration. Sci. Guaianae 1995, 5, 37-64.

38. Halbmayer, E. Contemporary Caribspeaking Amerindians. A Bibliography of Social Anthropological and Linguistic Resources; Difo-Druck: Bavaria, Germany, 2013.

39. Steyermark, J.; Berry, P.; Holts, B.; Yatskievych, K. Flora of the Venezuelan Guayana, Volume 1: Introduction; Missouri Botanical Garden Press: St. Louis, MO, USA, 1995; ISBN 9780915279739.

40. Hernández, L. Ecología de la Altiplanicie de la Gran Sabana (Guayana Venezolana). In Estructura, Diversidad, Crecimiento y Adaptación en Bosques de las Subcuencas de los Ríos Yuruan| y Alto Kukenán (Ecology of the High Plateau of the Gran Sabana (Venezuelan Guyana). In Structure, Diversity, Growth and Adaptation in Forests of the Sub-basins of the Yuruaní and Upper Kukenán Rivers). Scientia Guayanae 1999, 9, 5-34. (In Spanish).

41. Huber, O.; Febres, G. Guía Ecológica de la Gran Sabana; The Nature Conservancy: Caracas, Venezuela, 2000.

42. Pires, J.M.; Prance, G.T. The vetation types of the Brazilian Amazon. In Key Environments Amazonia; Prance, G.T., Lovejoy, T.E., Eds.; Pergamon Press: Oxford, UK, 1985; pp. 109-145.

43. Fundacao do Meio Ambiente e Tecnologia de Roraima. O Hemisferio Norte: Diagnostico Científico e Tecnológico para o Desenvolvimento (The Northern Hemisphere: Scientific and Technological Development Diagnostics); Fundacao do Meio Ambiente e Tecnologia de Roraima: Boa Vista, Cape Verde, 1994. (In Portuguese)

44. Barbosa, R.I. Distribuição das chuvas em Roraima (Rainfall distribution in Roraima). In Homem, Ambiente e Ecologia em Roraima (Man, Environment and Ecology in Roraima); Barbosa, R.I., Ferreira, E., Castellon, E.G., Eds.; Instituto Nacional de Pesquisas da Amazonia (INPA): Manaus, Amazonas, Brazil, 1997; pp. 325-335. (In Portuguese)

45. Hawkes, M.D.; Wall, J.R.D. The Commonwealth and Government of Guyana Rain Forest Programme, Phase I, Site Resource Survey, Main Report; Natural Resources Institute: Chatham, UK, 1993.

46. Persaud, C. Mean Annual and Monthly Rainfall Maps of Guyana; Caribbean Meteorological Institute: Barbados, Caribbean, 1994.

47. Barbosa, R.I.; Fearnside, F.M. Fire frequency and area burned in the Roraima savannas of Brazilian Amazonia. For. Ecol. Manag. 2005, 204, 371-384. [CrossRef]

48. Hardesty, J.; Myers, R.L.; Fulks, W. Fire, ecosystems, and people: A preliminary assessment of fire as a global conservation issue. Georg. Wright Forum 2005, 22, 78-87. 
49. Bilbao, B.A.; Leal, A.; Mendez, C.; Osío, A.; Hasmy, Z. Significado ecológico de las sabanas y zonas de transición sabana-Bosque en el mosaico de vegetación de la Gran Sabana, Parque Nacional Canaima. En Experiencias de Restauración Ecológica en Venezuela en las Últimas Décadas (Ecological significance of the savannas and savanna-forest transition zones in the vegetation mosaic of the Gran Sabana, Canaima National Park. In Experiences of Ecological Restoration in Venezuela in the Last Decades); Herrera, F., Herrera, I.Y., Eds.; Editores IVIC: Caracas, Venezuela, 2011; ISBN 1122-8060. (In Spanish)

50. Pivello, V.R. The use of fire in the cerrado and Amazonian rainforests of Brazil: Past and present. Fire Ecol. 2011, 7, 24-39. [CrossRef]

51. Simon, M.F.; Grether, R.; Queiroz, L.P.; Skema, C.; Pennington, R.T.; Hughes, C.E. Recent assembly of the Cerrado, a neotropical plant diversity hotspot, by in situ evolution of adaptations to fire. Proc. Natl. Acad. Sci. USA 2009, 106, 20359-20364. [CrossRef] [PubMed]

52. Roosevelt, A.C. Amazonian anthropology: Strategy for a new synthesis. In Amazonian Indians from Prehistory to Present: Anthropological Perspective; Roosevelt, A.C., Ed.; University of Arizona Press: Tucson, AZ, USA, 1994; pp. 1-29.

53. Welch, J.R.; Brondízio, E.S.; Hetrick, S.S.; Coimbra, C.E., Jr. Indigenous burning as conservation practice: Neotropical savanna recovery amid agribusiness deforestation in Central Brazil. PLoS ONE 2013, 8, e81226. [CrossRef] [PubMed]

54. Hernández, L.; Dezzeo, N.; Sanoja, E.; Salazar, L.; Castellanos, L. Changes in structure and composition of evergreen forests on an altitudinal gradient in the Venezuelan Guayana Shield. Rev. Biol. Trop. 2012, 60, 11-33. [CrossRef]

55. Leonel, M.M. O uso do fogo: O manejo indígena e a piromania da monoculture (The use of fire: Indigenous management and pyromania of monoculture). Estudos Avançados 2002, 14, 231-250. (In Portuguese) [CrossRef]

56. Nevle, R.J.; Bird, D.K. Effects of syn-pandemic fire reduction and reforestation in the tropical Americas on atmospheric $\mathrm{CO}_{2}$ during European conquest. Palaeogeogr. Palaeoclimatol. Palaeocol. 2008, 264, 25-38. [CrossRef]

57. Moura, L.C.; Scariotb, A.O.; Schmidta, I.B.; Beatty, R.; Russell-Smith, J. The legacy of colonial fire management policies on traditional livelihoods and ecological sustainability in savannas: Impacts, consequences, new directions. J. Environ. Manag. 2019, 232, 600-606. [CrossRef]

58. Schmidt, I.B.; Moura, L.C.; Ferreira, M.C.; Eloy, L.; Sampaio, A.B.; Dias, P.A.; Berlinck, C.N. Fire management in the Brazilian Savanna: First steps and the way forward. J. Appl. Ecol. 2018, 55, 2094-2101. [CrossRef]

59. Ratter, J.A.; Bridgewater, S.; Ribeiro, J.F. Biodiversity patterns of woody cerrado vegetation: An overall view. Ann. Bot. 1997, 80, 223-230. [CrossRef]

60. Cochrane, M. Fire, land use, land cover dynamics, and climate change in the Brazilian Amazon. In Tropical Fire Ecology: Climate Change, Land Use and Ecosystem Dynamics; Cochrane, M., Ed.; Springer: Heidelberg, Germany, 2009; pp. 389-426.

61. Aragão, L.E.O.C.; Shimabukuro, Y.E. The incidence of fire in Amazonian forests with implications for REDD. Science 2010, 328, 1275-1278. [CrossRef] [PubMed]

62. Vieira, R.S.; Pressey, R.L.; Loyola, R. The residual nature of protected areas in Brazil. Biol. Conserv. 2019, 232, 152-161. [CrossRef]

63. Durigan, G.; Ratter, J.A. The need for a consistent fire policy for Cerrado conservation. J. Appl. Ecol. 2016, 53, 11-15. [CrossRef]

64. Ley Penal del Ambiente, República Bolivariana de Venezuela. Gaceta Oficial No. 39.913 (Official Gazette No. 39,913); Mayo Clinic: Caracas, Venezuela, 2012. (In Spanish)

65. Guyana Forestry Commission (GFC). An Overview of Forest Fire Management in Guyanas. In Proceedings of the Second Regional Seminar on Forest Fires in The Amazon Region; Sao Paulo, Brazil, 17-21 October 2016, Inpe-São José dos Campos: Sao Paulo, Brazil, 2016.

66. Constitución de la República Bolivariana de Venezuela, República Bolivariana de Venezuela. Gaceta Oficial Extraordinaria No. 5.453 (Official Gazette Extraordinary No. 5.453); Servicio Autónomo Imprenta Nacional: Caracas, Venezuela, 2000. (In Spanish) 
67. Bevilacqua, M.; Medina, D.A.; Cárdenas, L. Manejo de recursos naturales en el parque nacional Canaima: Desafíos institucionales para su conservación. (Natural Resource Management in Canaima National Park: Institutional Challenges for Conservation.) In Biodiversidad del Parque Nacional Canaima (Biodiversity of Canaima National Park); Fundación La Salle: Caracas, Venezuela, 2009; pp. 157-169. (In Spanish)

68. Sletto, B. Indigenous people don't have boundaries: Reborderings, fire management, and productions of authenticities in Indigenous landscapes. Cult. Geogr. 2009, 16, 253-277. [CrossRef]

69. Rodriguez, I.; Sletto, B.; Bilbao, B.; Leal, A. landscapes. In STEPS Working Paper 54; STEPS Centre: Brighton, UK, 2013.

70. Howitt, R.; Doohan, K.; Suchet-Pearson, S.; Cross, S.; Lawrence, K.; Lunkapis, G.J.; Muller, S.; Prout, S.; Veland, S. Intercultural capacity deficits: Contested geographies of coexistence in natural resource management. Asia Pac. Viewp. 2013, 54, 126-140. [CrossRef]

71. Checkland, P. Systems Thinking, Systems Practice; Wiley: Chichester, UK, 1981.

72. Ison, R.; Blackmore, C.; Collins, K.; Furniss, P. Systemic environmental decision making: Designing learning systems. Kybernetes 2007, 36, 1340-1361. [CrossRef]

73. Checkland, P. La Metodología de Sistemas Blandos. In Análisis Racional Reestudiado Para un Mundo Problemático (The Soft Systems Methodology. In: Rational Analysis Restudied For a Problematic World); Rosenhead, J., Mingers, J., Eds.; Instituto Venezolano de Planificación: Caracas, Venezuela, 2004; pp. 69-101. ISBN 980-6793-16-1. (In Spanish)

74. Bell, S.; Berg, T.; Morse, S. Rich Pictures: Encouraging a Resilient Community; Routledge: London, UK; New York, NY, USA, 2016.

75. Couprie, D.; Goodbrand, A.; Li, B.; Zhu, D. Soft Systems Methodology. Available online: http://sern.ucalgary. ca/courses/seng/613/F97/grp4/ssmfinal.html\#TOP (accessed on 30 May 2019).

76. Millán, A.; Bilbao, B.; Yerena, E. Intercultural Fire Management as a Tool for the Conservation of Canaima National Park, Venezuelan Guyana (in Spanish: Manejo intercultural del fuego como herramienta para la conservación del Parque Nacional Canaima, Guayana Venezolana). In Proceedings of the 3rd International Congress on Biodiversity of the Guiana Shield, Paramaribo, Suriname, 5-8 August 2013.

77. García, S.; Bilbao, B.; Taller, I. Aunando perspectivas para la creación de una política para la creación de una política ambiental legítima y efectiva del manejo del fuego en el Parque Nacional Canaima (Uniting perspectives for creating a legitimate and effective environmental fire management policy in Canaima National Park). In Proceedings of the 7th Congreso Venezolano de Ecología, La Sociedad es parte del Ecosistema, Ciudad Guayana, 5-9 November 2007; Señaris, J.C., Rojas, H., Lew, D., Eds.; Sociedad Venezolana de Ecología: Ciudad Guayana, Venezuela, 2007; pp. 144-154. (In Spanish).

78. Gómez, E.; Picón, G.; Bilbao, B. Los incendios forestales en Iberoamérica. Caso Venezuela. In The Defense Against Forest Fires. Fundamentals and Experience); Vélez-Muñoz, R., Ed.; McGraw-Hill: Madrid, España, 2000; pp. 22.3-22.42. (In Spanish)

79. EDELCA. La Cuenca del Caroní. Una Visión en Cifras (The Caroní Basin. A Vision in Numbers); CVG-EDELCA: Puerto Ordaz, Venezuela, 2008; p. 263. (In Spanish)

80. Falleiro, R.M. Resgate do manejo tradicional do Cerrado com fogo para proteção das Terras Indígenas do oeste do Mato Grosso: Um estudo de caso (Rescue of the traditional management of the Cerrado with fire to protect the Indigenous Lands of western Mato Grosso: A case study). Biodiversidade Brasileira 2011, 30, 86-96. (In Portuguese)

81. Reyes-García, V.; Broesch, J.; Calvet-Mir, L.; Fuentes-Peláez, N.; McDade, T.W.; Parsa, S.; Tannerg, S.; Huancah, T.; Leonarde, W.R.; Martínez-Rodríguez, M.R. Cultural transmission of ethnobotanical knowledge and skills: An empirical analysis from an Amerindian society. Evol. Hum. Behav. 2009, 30, 274-285. [CrossRef]

82. Shishkava, D. Culture Change in the Pemón Society. Risks and Changes for an Indigenous Group in Venezuela. Master's Thesis, Karlsruhe Institute of Technology (KIT), Karlsruhe, Germany, 2015.

83. Kingsbury, N.D. Impacts of land use and cultural change in a fragile environment: Indigenous acculturation and deforestation in Kavanayen, Gran Sabana, Venezuela. Interciencia 2001, 26, 327-336.

84. Atran, S.; Sperber, D. "Learning without teaching: Its place in culture." In Annual Workshop on Culture, Schooling and Psychological Development, 4th, Jun, 1987, Tel Aviv U, Ramat Aviv, Israel; Ablex Publishing: New York, NY, USA, 1991. 
85. Berkes, F.; Colding, J.; Berkens, C.F. Rediscovery of traditional knowledge as adaptive management. Ecol. Appl. 2000, 10, 1251-1262. [CrossRef]

86. Klubnikin, K.; Annett, C.; Cherkasova, M.; Shishin, M.; Fotieva, I. The sacred and the scientific: Traditional ecological knowledge in Siberian river conservation. Ecol. Appl. 2000, 10, 1296-1306. [CrossRef]

87. Davis, M. Bridging the gap or crossing a bridge? Indigenous knowledge and the language of law and policy. In Bridging Scales and Knowledge Systems: Concepts and Applications in Ecosystem Assessment; Reid, W.V., Berkes, F., Wilbanks, T.J., Capistrano, D., Eds.; Island Press: Washington, DC, USA, 2006; pp. 145-163.

88. Berry, J.W. Immigration, acculturation, and adaptation. J. Appl. Psychol. 1997, 46, 5-34. [CrossRef]

89. ISA. Povos Indigenas do Brasil, Macuxi. Available online: https://pib.socioambiental.org/pt/Povo:Macuxi (accessed on 10 January 2019).

90. Keenleyside, K.A.; Dudley, N.; Cairns, S.; Hall, C.M.; Stolton, S. Restauración Ecológica Para Áreas Protegidas: Principios, Directrices y Buenas Practices (Ecological Restoration for Protected Areas: Principles, Guidelines and Good Practices); UICN: Gland, Switzerland, 2014; ISBN 978-2-8317-1678-7. (In Spanish)

91. Ceccon, E. Restauración en Bosques Tropicales: Fundamentos Ecológicos, Prácticos y Sociales (Tropical Forest Restoration: Ecological, Practical and Social Fundamentals), 1st ed.; CRIM/UNAM-Díaz de Santos: Ciudad de Mexico, Mexico, 2013. (In Spanish)

92. Petty, A.M.; deKoninck, V.; Orlove, B. Cleaning, protecting, or abating? Making Indigenous fire management "work" in northern Australia. J. Ethnobiol. 2015, 35, 140-162. [CrossRef]

93. Fache, E.; Moizo, B. Do burning practices contribute to caring for country? Contemporary uses of fire for conservation purposes in Indigenous Australia. J. Ethnobiol. 2015, 35, 163-182. [CrossRef]

94. Perry, J.J.; Sinclair, M.; Wikmunea, H.; Wolmby, S.; Martin, D.; Martin, B. The divergence of traditional Aboriginal and contemporary fire management practices on Wik traditional lands, Cape York Peninsula, Northern Australia. Ecol. Manag. Restor. 2018, 19, 24-31. [CrossRef]

95. Goldman, M.; Nadasdy, P.; Turner, M.D. Knowing Nature: Conversation at the Intersection of Political Ecology and Science Studies; Goldman, M., Nadasdy, P., Turner, M.D., Eds.; The University of Chicago Press: Chicago, IL, USA, 2011.

96. Kettle, N.P.; Dow, K.; Tuler, S.; Webler, T.; Whitehead, J.; Miller, K.M. Integrating scientific and local knowledge to inform risk-based management approaches for climate adaptation. Clim. Risk Manag. 2014, 4-5, 17-31. [CrossRef]

97. Millán, A. Bases Para la Creación de un Plan de Manejo Integral del Fuego en el Parque Nacional Canaima (Bases for the Creation of an Integrated Fire Management Plan in Canaima National Park); Universidad Simón Bolívar: Caracas, Venezuela, 2015. (In Spanish)

98. Nadasdy, P. The politics of TEK: Power and the "integration" of knowledge. Arct. Anthropol. 1999, 36, 1-18.

99. Moorcroft, H.; Ignjic, E.; Cowell, S.; Goonack, J.; Mangolomara, S.; Oobagooma, J.; Karadada, R.; Williams, D.; Waina, N. Conservation planning in a cross-cultural context: The Wunambal Gaambera Healthy Country Project in the Kimberley, Western Australia. Ecol. Manag. Restor. 2012, 13, 16-25. [CrossRef]

100. North Rupununi District Development Board. Available online: http://nrddb.org/aboutNorthRupununi (accessed on 18 January 2019).

101. United Nations Development Programme. Instituto Raoni, Brazil; Equator Initiative Case Study Series; Equator Initiative: New York, NY, USA, 2018.

(C) 2019 by the authors. Licensee MDPI, Basel, Switzerland. This article is an open access article distributed under the terms and conditions of the Creative Commons Attribution (CC BY) license (http://creativecommons.org/licenses/by/4.0/). 